\title{
Overexpressing miR-335 inhibits DU145 cell proliferation by targeting early growth response 3 in prostate cancer
}

\author{
PENG ZHANG* , XIAOJIE YANG * LI WANG, DONG ZHANG, \\ QIDONG LUO and BINXIAN WANG \\ Department of Urinary Surgery, The Second Affiliated Hospital of \\ Xi'an Jiaotong University, Xi'an, Shanxi 710004, P.R. China
}

Received August 30, 2018; Accepted March 18, 2019

DOI: $10.3892 /$ ijo.2019.4778

\begin{abstract}
MicroRNA-335 (miR-335) was reported to suppress cell proliferation in prostate cancer ( $\mathrm{PC}$ ), a common malignancy in males. The expression of early growth response 3 (EGR3) was determined to be elevated in human PC tissues; however, the possible effects and underlying mechanism of miR-335 on $\mathrm{PC}$ remains unknown. In the present study, miR-335 mimics and miR-335 inhibitors were respectively transfected into DU145 cells. Stable silencing of EGR3 was observed in DU145 cells following transfection with small interfering RNA. We also used Cell Counting Kit-8 and in vitro angiogenesis assays to determine the viability and revascularization potential of DU145 cells. The expression levels of EGR and caspase-3 activity were analyzed by immunohistochemistry and immunocytochemistry, respectively. We predicted the target of miR-335 by bioinformatics analysis and a dual-luciferase reporter gene assay. Western blot and quantitative real-time polymerase chain reaction analyses were performed to determine the protein and mRNA expression of molecules. miR-335 expression was downregulated in PC tissues and cell lines. Overexpression of miR-335 significantly reduced the viability and the formation of regenerative tubes of DU145 cells, and inhibited the expression of inflammatory factors. EGR3 was proposed as a possible target of miR-335, and was negatively regulated by miR-335. Silencing EGR3 suppressed the viability and angiogenesis of DU145 cells, and reduced the activity of caspase-3 and inflammatory factor expression. miR-335 inhibition along with EGR3 silencing
\end{abstract}

Correspondence to: Dr Peng Zhang, Department of Urinary Surgery, The Second Affiliated Hospital of Xi'an Jiaotong University, 157 Xiwu Road, Xincheng, Xi'an, Shanxi 710004, P.R. China

E-mail: zpeng_zhangp@163.com

${ }^{*}$ Contributed equally

Key words: microR-335, early growth response 3, prostatic carcinoma, angiogenesis
EGR3 inhibited the cell proliferation. Furthermore, miR-335 inhibited the formation of a PC solid tumor xenograft in vivo. Thus, miR-335 may exert an antitumor effect on DU145 cells by regulating the expression of EGR3. The findings of the present study may provide insight into a novel therapeutic strategy for the treatment of prostatic carcinoma.

\section{Introduction}

Prostate cancer (PC) is a common malignant cancer that often occurs in aged males and is the second leading cause of cancer-associated mortality $(1,2)$. As of its notable heterogeneity, PC is difficult to diagnose according to current diagnostic and prognostic indexes; for example, an underestimated Gleason score and elevated levels of prostate specific antigen in the serum of patients with prostatitis and benign prostatic hyperplasia $(3,4)$. Given the molecular heterogeneity of PC (5), its diagnosis, treatment and prognosis may be improved by further investigations into the translation of several molecular markers in specific stages of disease (6). Recently, the roles of micro (miRNAs/miRs) in PC have been widely studied, and aberrant miRNAs expression has been regarded as crucial biomarkers for the diagnosis, grading and prognosis of PC $(7,8)$. miRNAs can regulate carcinogenesis of prostate tissue by interacting with their target genes $(9,10)$. Therefore, it is necessary to explore the regulatory mechanism of miRNA, which may provide insight into novel therapeutic strategies for the treatment of PC.

As small, non-coding and single-stranded RNAs, the endogenously expressed miRNAs can reversely mediate the expression of target genes at the post-transcriptional level, and inhibit translation or induce mRNA degradation to activate various pathways mainly by binding to the 3 '-untranslated region (3'-UTR) (11-13). It has been demonstrated that miR-335 is an important miRNA associated with numerous types of cancer (14). For instance, the overexpression of miR-335 has been reported to suppress the metastatic invasion of breast cancer (BCa) cells (15). It was revealed that reduced miR-335 expression in $\mathrm{BCa}$ tissues is associated with the clinicopathological characteristics of BCa (16). Additionally, miR-335 has been demonstrated to be related 
to the chemoresistance of ovarian cancer cells (17). On the contrary, in astrocytoma cells, miR-335 can promote tumor growth and invasion by targeting a potential tumor inhibitor, while miR-335 inhibition could notably induce growth arrest and apoptosis in vitro and in vivo (18). Furthermore, miR-335 expression is dysregulated in several cancers, including hepatocellular carcinoma, meningioma, PC and colorectal cancer (19-22). Additionally, miR-335 was reported to possess diverse targets in the same cancer $(23,24)$. Therefore, exploring the target genes of miR-335 may reveal novel therapeutic targets.

Early growth response (EGR) transcription factors can be induced in a variety of cells to respond to stimuli, including stress, hypoxia, injury, cytokines and growth factors (25). In the EGR family of proteins, EGR1 has been reported to be associated with inflammation, ischemic injury and atherosclerosis (26), in addition to its antitumor effects by inducing apoptosis in cancer (27-29). However, to the best of our knowledge, the number of the studies on EGR3 is limited. A recent study has suggested that high expression of EGR3 in A549 cells could inhibit cell growth and is associated with improved prognosis in lung adenocarcinoma (30). Conversely, elevated EGR3 expression was determined to be associated with poor prognosis in PC (31). Furthermore, EGR3 can regulate the levels of inflammatory cytokines, including interleukin-6 (IL-6) and IL-8 in PC cells, and these cytokines can exert critical effects on the development of PC (32). Considering the roles of miR-335 and EGR3 in the PC, we aimed to examine whether miR-335 exhibits anticancer effects by regulating its potential target gene EGR3.

\section{Materials and methods}

Prostate tissue specimens. The present study was approved by the Ethics Committee of The Second Affiliated Hospital of Xi'an Jiaotong University and informed consent was obtained from each patient. A total of 53 male patients in our hospital from December 2017 to January 2018 were enrolled in this study: 36 patients with prostate cancer (mean age, 68.2; age range, 55-82 years) and 18 patients with metastatic prostate cancer (mean age, 72.4; age range, 58-86 years). Patients with prostate cancer included in the present study received no preoperative medication and had no history of surgical castration or radiotherapy. Fifty-three PC tissues and matched normal tissues from patients were frozen for reverse transcription-quantitative polymerase chain reaction (RT-qPCR) analysis and immunohistochemistry (IHC).

Cell culture. Human umbilical vein endothelial cells (HUVECs) were purchased from Promocell (Jiangyin, China) and cultured in endothelial cell growth medium (Promocell). DU145 and PC-3M cells (human prostate carcinoma cell line) were obtained from the American Type Culture Collection (Manassas, VA, USA) and maintained in RPMI-1640 medium (Sigma-Aldrich; Merck KGaA, Darmstadt, Germany) containing 10\% fetal bovine serum (Thermo Fisher Scientific, Inc., Waltham, MA, USA), 2 mM L-glutamine (Gibco; Thermo Fisher Scientific, Inc.) and $1 \%$ antibiotic mixture (penicillin and streptomycin; Gibco;
Thermo Fisher Scientific, Inc.) at $37^{\circ} \mathrm{C}$ in a humidified incubator with $5 \% \mathrm{CO}_{2}$.

Cell transfection. The prostate cancer DU145 Cells $\left(2 \times 10^{5}\right)$ were transfected with miR-335 mimics (5'-UCAAGAGCAA UAACGAAAAAUGU-3'), miR-335 inhibitors (5'-ACAUUU UUCGUUAUUGCUCUUGA-3') and corresponding controls (Thermo Fisher Scientific, Inc.) using Lipofectamine ${ }^{\circledR} 2000$ (Invitrogen; Thermo Fisher Scientific, Inc.) at a final concentration of $50 \mathrm{nM}$ according to the manufacturer's protocols. The PC-3M cells were only transfected with miR-335 mimics and corresponding controls. To knockdown EGR3, DU145 cells were transfected with $30 \mathrm{nM}$ small interfering RNA (siRNA) against EGR3 (siEGR3; \#115514; Ambion, Austin, TX, USA) and negative controls (siNC; \#4642; Ambion) using siPORT NeoFX (Ambion) according to the manufacturer's protocol and incubated for $24 \mathrm{~h}$. The sequence of siRNAs for EGR3 was 5'-CCAACACAACAGAUAGAAUtt-3'. Puromycin was used to select transfected cells. In addition, siEGR3 and miRNAs were co-transfected into DU145 cells at a concentration of $50 \mathrm{nM} /$ well. At $48 \mathrm{~h}$ after transfection, cells were harvested for further analyses. Non-transfected cells were served as another control.

Cell viability assay. Transfected cells (1x104) were cultivated for 24, 48 and $72 \mathrm{~h}$, respectively. Subsequently, $10 \mu \mathrm{l}$ Cell Counting Kit-8 solution (Beyotime Institute of Biotechnology, Shanghai, China) was added into the cells at each time point. After the cells were incubated for $2 \mathrm{~h}$ at $37^{\circ} \mathrm{C}$, the optical density at $450 \mathrm{~nm}$ was measured with a FlexStation 3 microplate reader (Molecular Devices, LLC, Sunnyvale, CA, USA).

Apoptosis analysis. Apoptosis was detected according to the protocols of the Annexin V-fluorescein isothiocyanate/propidium iodide apoptosis detection kit (Nanjing KeyGen Biotech, Co., Ltd., Nanjing, China). The results were analyzed with a FACSCalibur flow cytometer (BD Biosciences, San Jose, CA, USA).

In vitro angiogenesis. HUVECs $\left(3 \times 10^{5}\right)$ were seeded with Matrigel (BD Biosciences) in a 96-well plate in the respective presence of supernatants comprising non-transfected DU145 cells, DU145 cells transfected with miR-NC or miR-335 mimics, DU145 cells transfected with miR-335 inhibitors, or DU145 cells transfected with siNC or siEGR3, and then incubated at $37^{\circ} \mathrm{C}$ for $15 \mathrm{~h}$. Then, the cells were fixed with $3.7 \%$ formaldehyde for $15 \mathrm{~min}$ at room temperature. The images of capillary-like structures from six replicates of each group were captured using an IX81 Olympus microscope (Olympus Corporation, Tokyo, Japan; magnification, x100). The overall length and cell junctions in each frame from five randomly selected fields were calculated using ImageJ v1.48 software (National Institutes of Health, Bethesda, MD, USA). Data were normalized to the controls.

Immunocytochemistry. For caspase-3 expression, the cells were immobilized in $4 \%$ paraformaldehyde for $24-48 \mathrm{~h}$ at room temperature and permeabilized in Tris-buffered saline with $0.1 \%$ Triton X-100 (TBST; pH 7.4; Sigma-Aldrich; Merck $\mathrm{KGaA}$ ). The cells were treated with $0.1 \% \mathrm{H}_{2} \mathrm{O}_{2}$ 
Table I. Sequences of primers used for reverse transcription-quantitative polymerase chain reaction.

\begin{tabular}{|c|c|c|}
\hline Gene & Forward $\left(5^{\prime}-3^{\prime}\right)$ & Reverse $\left(5^{\prime}-3^{\prime}\right)$ \\
\hline miR-335 & GTCGTATCCAGTGCAGGGTCCG & GTGCAGGGTCCGACCT \\
\hline EGR3 & TTCGCTTTCGACTCTCC & CTCCGAGTAGAGATCGC \\
\hline IL-6 & AAATTCGGTACATCCTCGACGGCA & AGTGCCTCTTTGCTGCTTTCACAC \\
\hline IL-8 & AGGACAAGAGCCAGGAAGAAACCA & AGAGCTGCAGAAATCAGGAAGGCT \\
\hline IL-1 $\beta$ & AACAGGCTGCTCTGGGATTCTCTT & AACAGGCTGCTCTGGGATTCTCTT \\
\hline U6 & CTCGCTTCGGCAGCACA & AACGCTTCACGAATTTGCGT \\
\hline$\beta$-actin & GTGACGTTGACATCCG & GAGCGTTTGTTGTACCT \\
\hline
\end{tabular}

miR, microRNA; EGR3, early growth response 3; IL, interleukin.

for $30 \mathrm{~min}$ at room temperature to inhibit endogenous peroxidase, followed by incubation with $5 \%$ normal goat serum (Vector Laboratories, Inc., Burlingame, CA, USA) for $40 \mathrm{~min}$ at room temperature to block non-specific binding sites. The cells were then incubated with anti-caspase-3 (1:50; cat. no. 9661, Cell Signaling Technology, Inc., Danvers, MA, USA) overnight at $4^{\circ} \mathrm{C}$ and then with a biotinylated goat anti-rabbit IgG (1:200) as a secondary antibody (BP-9100, Vector Laboratories, Inc.) for $1 \mathrm{~h}$ at room temperature. Subsequently, the cells were washed in TBST and incubated with avidin-biotin-peroxidase complex (1:1:100; Strept ABC complex/HRP; Dako; Agilent Technologies, Inc., Santa Clara, CA, USA) for $45 \mathrm{~min}$ in dark at room temperature. The results was visualized with 3'3'-diaminobenzidene (DAB; Vector Laboratories, Inc.) for $10 \mathrm{~min}$ at room temperature and stained with hematoxylin (Sigma-Aldrich; Merck $\mathrm{KGaA}$ ) for $30 \mathrm{sec}$ at room temperature.

Target prediction. To predict the potential targets of miR-335, TargetScan 7.2 (http://www.targetscan.org) was utilized and the candidate targets were identified based on the phenotype of miR-335.

Luciferase assay. DU145 cells were transfected with a firefly luciferase reporter pGL3 vector (Promega Corporation, Madison, WI, USA) containing the wild-type or mutant EGR3 3'-UTR, the control pRL-TK vector containing Renilla luciferase (Promega) with miR-335 mimics and miR-335 inhibitors using Lipofectamine 2000. The cells were maintained for $24 \mathrm{~h}$ and the activities of firefly and Renilla luciferase were determined by Dual-Luciferase Reporter Assay System (Promega Corporation).

RNA extraction, $c D N A$ synthesis and RT-qPCR. Total RNA of prostate tissues and DU145 cells was extracted using TRIzol (Invitrogen; Thermo Fisher Scientific, Inc.). In brief, TRIzol reagent and $200 \mathrm{ml}$ chloroform were added to samples and mixed for $5 \mathrm{~min}$, followed by centrifugation $(12,000 \mathrm{x} \mathrm{g}$ for $15 \mathrm{~min}$ at $4^{\circ} \mathrm{C}$ ) to recover the supernatant. Then, the supernatant was incubated with an equal volume of isopropyl alcohol for $10 \mathrm{~min}$ at room temperature and centrifuged at $12,000 \mathrm{x} \mathrm{g}$ for $15 \mathrm{~min}$ at $4^{\circ} \mathrm{C}$. After dislodging the supernatant, $75 \%$ ethanol was added to for precipitation and the RNA was eluted with nuclease-free water. For the RT, the concentration and purity were detected by a NanoDrop 2000 spectrophotometer (NanoDrop Technologies; Thermo Fisher Scientific, Inc.). cDNA was obtained from $1 \mu \mathrm{g}$ RNA at $25^{\circ} \mathrm{C}$ for $10 \mathrm{~min}, 37^{\circ} \mathrm{C}$ for $120 \mathrm{~min}$ and $85^{\circ} \mathrm{C}$ for $5 \mathrm{~min}$ using the High Capacity cDNA Reverse Transcription Kit (Applied Biosystems; Thermo Fisher Scientific, Inc.). The qPCR reaction system was as follows: $2.5 \mu \mathrm{l}$ dNTPs $(2.5 \mathrm{mM}) ; 2.5 \mu 1$ 10X PCR buffer; $1.5 \mu 1 \mathrm{MgCl}_{2}$ solution; 1 unit Taq polymerase; $0.25 \mathrm{X}$ SYBR Green I (Sigma-Aldrich; Merck KGaA); $1 \mu \mathrm{l}$ primers $(10 \mu \mathrm{M}$ each); $1 \mu \mathrm{l}$ cDNA; water (to a total volume of $25 \mu \mathrm{l}$ ). The qPCR reactions were conducted with a LightCycler system (Roche Applied Science, Indianapolis, IN, USA) using the following parameters: $95^{\circ} \mathrm{C}$ for $10 \mathrm{~min}, 40$ cycles at $95^{\circ} \mathrm{C}$ for $10 \mathrm{sec}$, at $60^{\circ} \mathrm{C}$ for $20 \mathrm{sec}$ and at $72^{\circ} \mathrm{C}$ for $30 \mathrm{sec}$. The specific primers were listed in Table I. U6 and $\beta$-actin served as the internal reference genes. Expression was calculated using the $2^{-\Delta \Delta C q}$ method (33).

Western blotting. The cells were lysed in lysis buffer (Beyotime Institute of Biotechnology, Shanghai, China) and centrifuged at $10,000 \mathrm{xg}$ for $10 \mathrm{~min}$ at $4^{\circ} \mathrm{C}$, and placed on ice for $30 \mathrm{~min}$ to obtain the supernatant. The protein concentration was determined using a BCA kit (Beyotime Institute of Biotechnology). After being separated by $10 \%$ SDS-PAGE ( $40 \mu \mathrm{g}$ protein was used), the proteins were transferred onto nitrocellulose membranes (EMD Millipore, Bedford, MA, USA) and blocked for $1 \mathrm{~h}$. The membranes were incubated overnight at $4^{\circ} \mathrm{C}$ with anti-EGR3 (1:500, sc-390967, Santa Cruz Biotechnology, Inc., Dallas, TX, USA), anti-IL-6 (1:1,000, ab9324, Abcam, Cambridge, USA), anti-IL-8 (1:1,000, ab18672, Abcam), anti-IL-1 $\beta$ (1:1,000, ab156791, Abcam) and anti- $\beta$-actin (1:1,000, sc-517582, Santa Cruz Biotechnology, Inc.) and incubated with secondary antibodies (1:1,000, HRP-labeled goat anti-mouse IgG, A0216, Beyotime Institute of Biotechnology) for $2 \mathrm{~h}$ at room temperature. Proteins were visualized with an ECL kit (GE Healthcare, Chicago, IL, USA). The Gray value was detected by ImageJ 1.48 software.

Xenograft experiment of prostate cancer. Female sever combined immunodeficient mice (20-22 g; $n=6 ; 6$ weeks old) were purchased from the Animal Experimental Center of Zhejiang Academy of Medical Sciences. Mice were housed in 

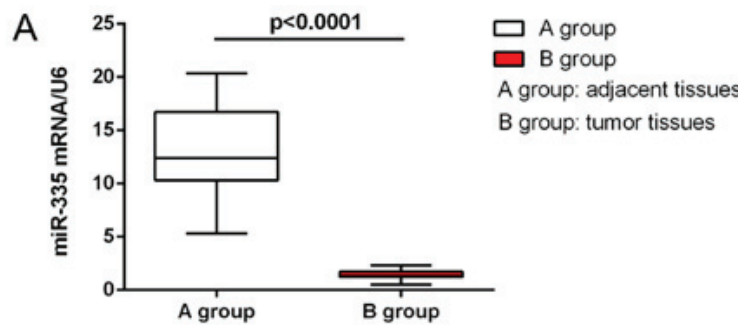

B group: tumor tissues
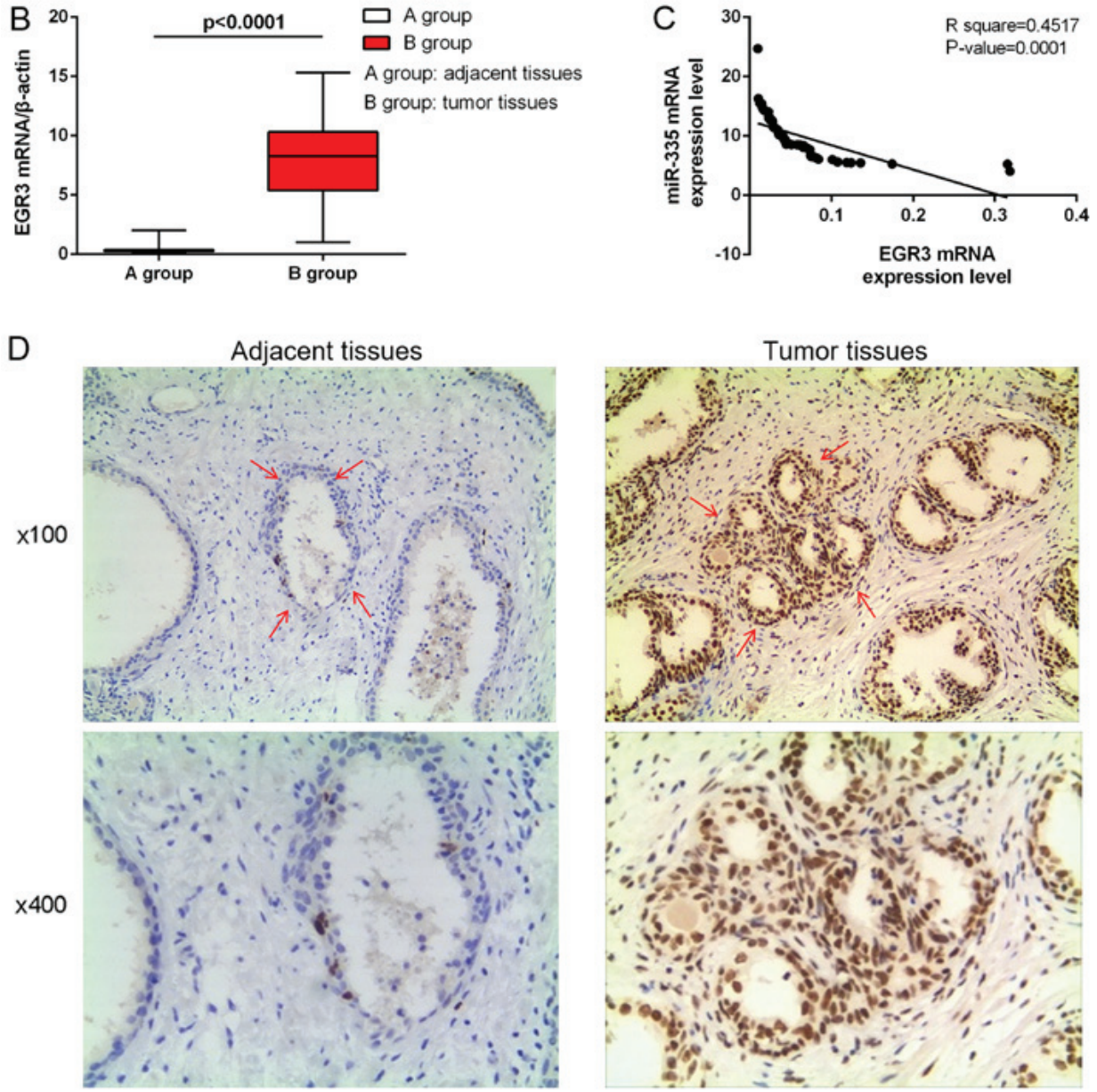

Figure 1. Expression of miR-335 and EGR3 in tissues of patients with PC. The expression of (A) miR-355 and (B) EGR3 in tumor tissues and match adjacent tissues of 53 patients were detected by reverse transcription-quantitative polymerase chain reaction. (C) Correlation between miR-335 expression and EGR3 mRNA expression. (D) EGR3 expression in prostate cancer tissues as determined by immunohistochemistry. Magnifications, x100 and 400 . Comparison of EGR3 expression between tumor prostate tissue and adjacent normal prostate tissue are indicated by red arrows. EGR3, early growth response 3; miR, microRNA.

cages at room temperature $\left(22 \pm 3^{\circ} \mathrm{C}\right)$ with constant humidity $(50 \pm 10 \%)$ with a free access to food and water under a light/dark cycle (12 h). The animal experiments were approved by The Second Affiliated Hospital of Xi'an Jiaotong University Animal Ethics Committee (approval no. JT201805032M) and according to the Guidelines for the Care and Use of Laboratory Animals (34).

PC-3M and DU145 cells were transfected with miR-335 mimic and miR-NC as aforementioned. PC model was induced by a hypodermic injection of $5 \times 10^{6}$ non-transfected or transfected cells into lateral abdominal wall of mice. Tumor volume was measured every 6 days for 42 days. The mice were sacrificed 42 days after the cell transplantation and weighing.
IHC. IHC was performed to detect the EGR3 expression in 53 prostate cancer tissues and matched adjacent tissues and in the PC xenograft tissues of mice as previously described (35). In brief, tissue sections $(4 \mu \mathrm{m})$ were dewaxed in $4 \%$ paraformaldehyde for $10 \mathrm{~min}$ at room temperature and rehydrated with gradient ethanol (Sigma-Aldrich; Merck $\mathrm{KGaA}$ ), followed by heat-induced antigen retrieval in $10 \mathrm{mM}$ sodium citrate ( $\mathrm{pH} \mathrm{6.0)}$ ) for $20 \mathrm{~min}$. Then the sections were blocked in $10 \%$ normal goat serum (Vector Laboratories, Inc.) at room temperature for $10 \mathrm{~min}$. Thereafter, the sections were incubated in $3 \% \mathrm{H}_{2} \mathrm{O}_{2}$ at room temperature for $30 \mathrm{~min}$ to inactivate endogenous peroxidase. The sections were subsequently incubated with the anti-EGR3 (1:50, sc-390967, Santa Cruz Technology, Inc.) overnight at $4^{\circ} \mathrm{C}$ and hybridized 
A

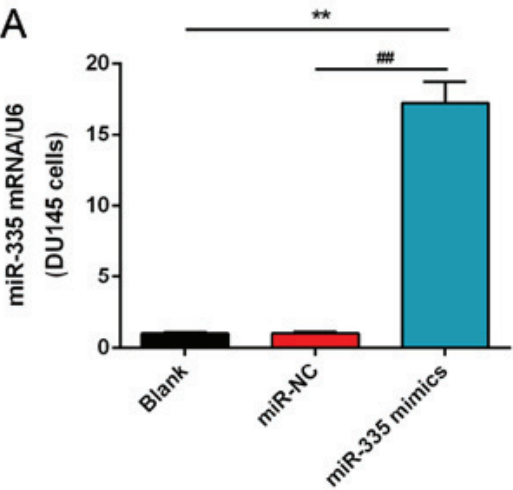

D

$\mathrm{Oh}$

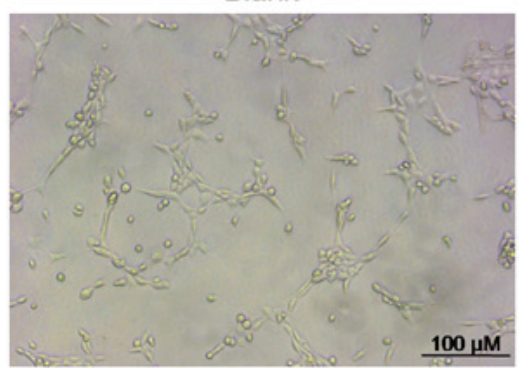

$24 \mathrm{~h}$

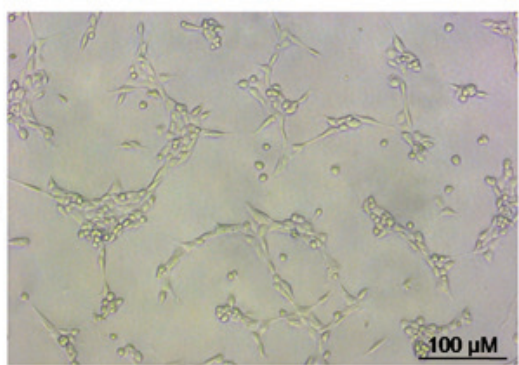

B

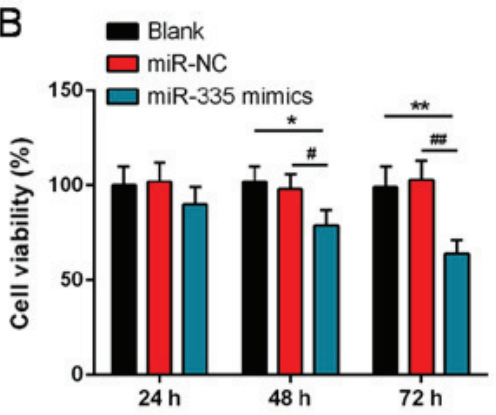

miR-NC
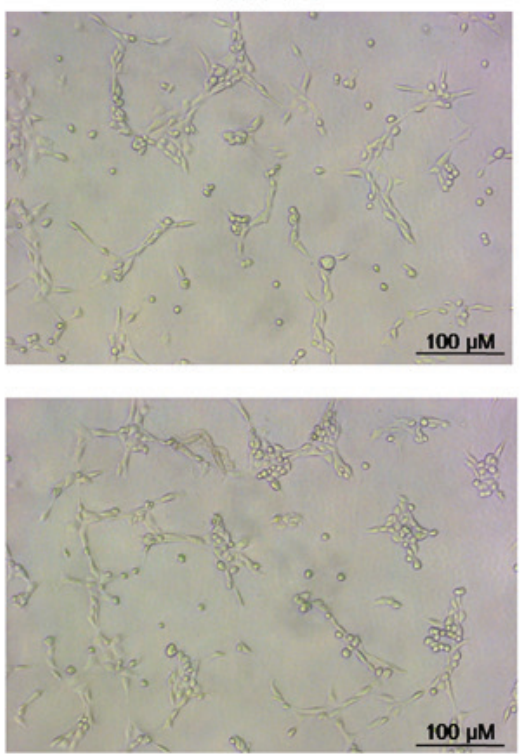

C

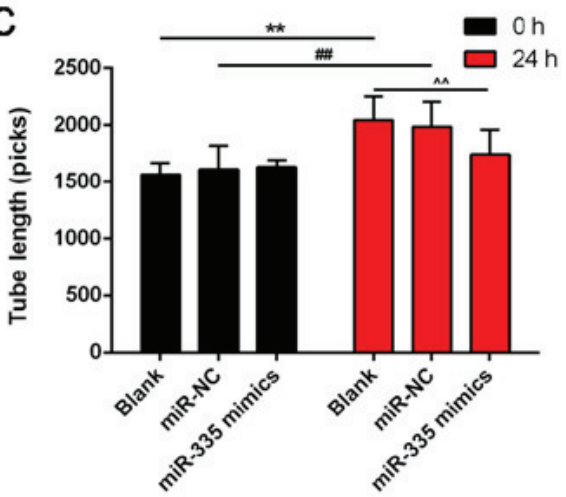

miR-335 mimics
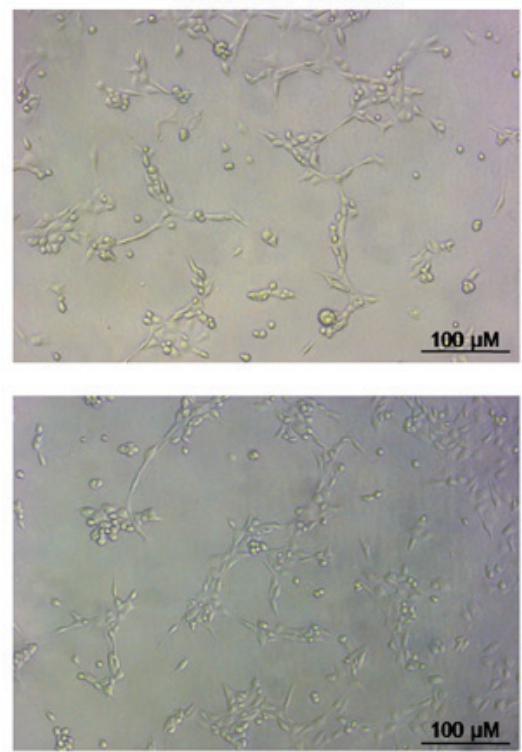

Figure 2. Overexpression of miR-335 inhibits viability and angiogenesis. (A) Elevated miR-335 expression indicted the successful transfection of miR-355 mimics. (B) Overexpression of miR-335 inhibited cell viability in a time-dependent manner. (C and D) The lengths and numbers of tubes were reduced following the overexpression of miR-335 in human umbilical vein endothelial cells. Scale bar $=100 \mu \mathrm{m}$. ${ }^{\prime} \mathrm{P}<0.05,{ }^{* *} \mathrm{P}<0.01,{ }^{\#} \mathrm{P}<0.05,{ }^{\# \#} \mathrm{P}<0.01,{ }^{\wedge \wedge} \mathrm{P}<0.01, \mathrm{n}=3$. Scale bar $=100 \mu \mathrm{m}$. miR, microRNA; NC, negative control.

with a biotinylated horse anti-mouse IgG secondary antibody (1:200, BP-2000, Vector Laboratories, Inc.) for $1 \mathrm{~h}$ at room temperature. The cells were washed in TBST and incubated with avidin-biotin-peroxidase complex (1:1:100; Strept ABC complex/HRP; Dako; Agilent Technologies, Inc.) for $45 \mathrm{~min}$ in dark at room temperature. DAB was then added to incubate for $10 \mathrm{~min}$ at room temperature and sections were stained with hematoxylin for $30 \mathrm{sec}$ at room temperature. The images were diagnosed under an Olympus microscope (Olympus Corporation; magnification, $\mathrm{x} 400$ ). Image-Pro Plus version 6.0 software (Media Cybernetics, Inc.) was used to evaluate the integrated optical density value of the tissue areas from five randomly selected fields.

Statistical analysis. All data were obtained from independent experiments and were presented as he mean \pm standard deviation. $\mathrm{P}<0.05$ was considered to indicate a statistically significant difference. A Student's t-test and one-way analysis of variance with a Dunnett's post-test were conducted using SPSS 17.0 software (SPSS, Inc. Chicago, IL, USA). Comparisons between tumor tissues and matched adjacent tissues were analyzed with an independent samples t-test. Correlations between miR-335 expression and EGR3 mRNA were analyzed by Spearman's correlation analysis.

\section{Results}

Expression of miR-335 and EGR3 in tissues of patients with $P C$. Among the 53 pairs of tissues, the expression levels of miR-335 in the prostate tumor tissues were significantly reduced than in normal tissues $(\mathrm{P}<0.0001$; Fig. 1A). On the contrary, EGR3 expression in tumor tissues was significantly elevated than in normal tissues $(\mathrm{P}<0.0001$; Fig. 1B). The expression of miR-335 was negatively correlated with that of EGR3 in patients with PC ( $\mathrm{P}=0.0001$; Fig. 1C). Furthermore, upregulated EGR3 expression was observed in cancer tissues (Fig. 1D).

Effects of miR-335 on cell viability and angiogenesis. The notably reduced expression of miR-335 in DU145 cells was significantly enhanced following transfecting cells with miR-335 mimics compared with the controls $(\mathrm{P}<0.01$; Fig. 2A). Additionally, miR-335 mimics significantly inhibited 

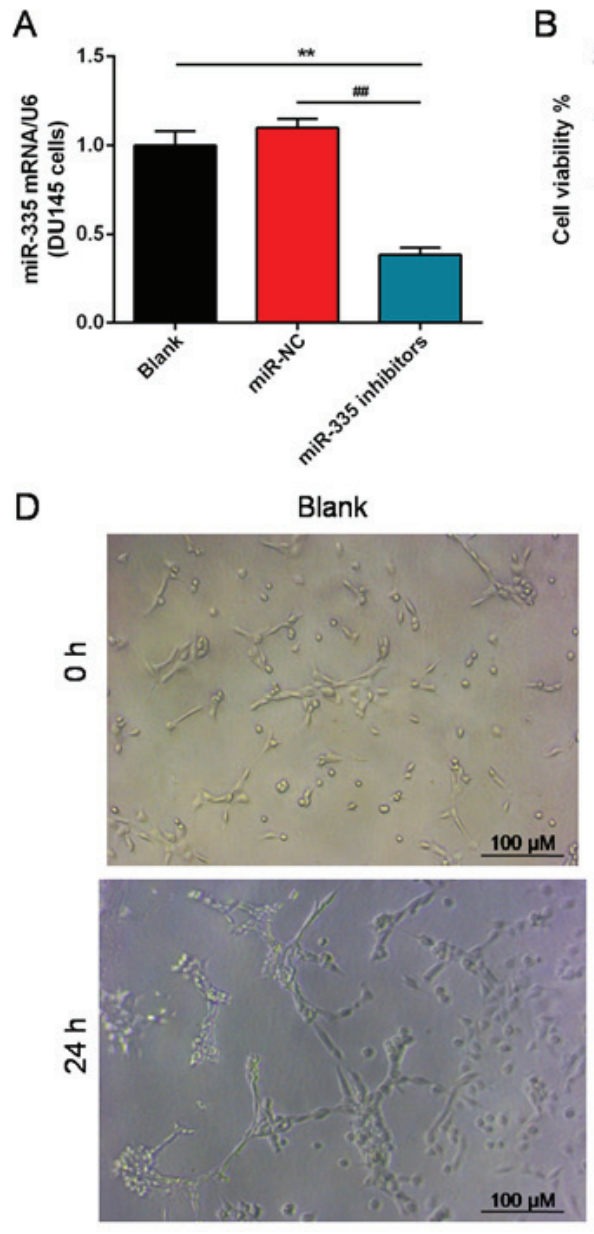
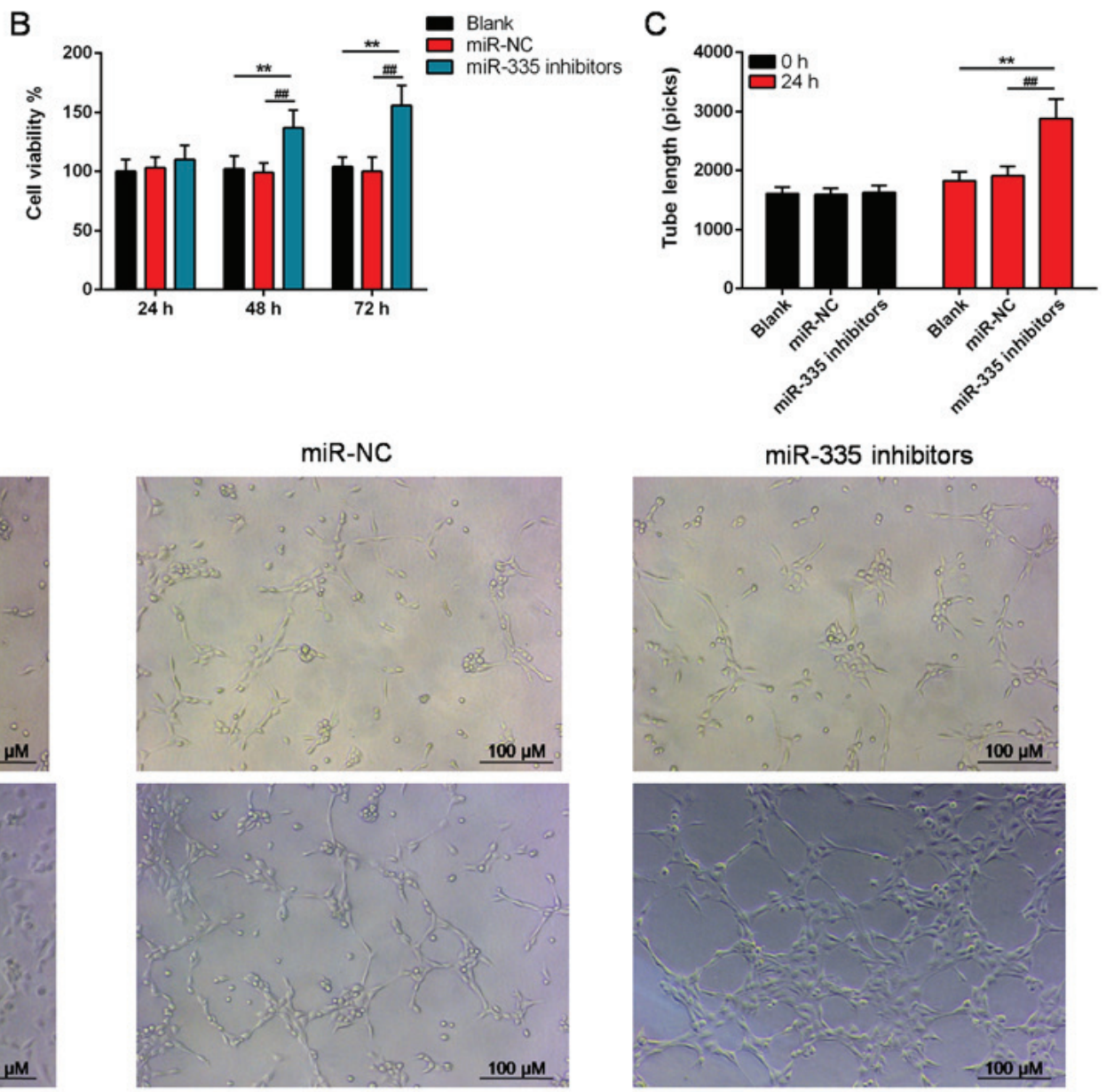

Figure 3. miR-335 knockdown promotes cell viability and angiogenesis. (A) miR-335 expression was significantly decreased following transfection with miR-355 inhibitors. (B) Silencing miR-335 in DU145 cells enhanced cell viability in a time-dependent manner. (C and D) miR-335 silencing increased the length and number of tubes in human umbilical vein endothelial cells. ${ }^{* *} \mathrm{P}<0.01,{ }^{\# \#} \mathrm{P}<0.01, \mathrm{n}=3$. miR, microRNA; NC, negative control.

cell viability after $48 \mathrm{~h}$ compared with the controls $(\mathrm{P}<0.01$; Fig. 2B). After $24 \mathrm{~h}$ of culture, the length of neoformative tubes of HUVECs was significantly suppressed by miR-335 mimics, compared with the blank and miR-NC groups $(\mathrm{P}<0.01$; Fig. 2C). In addition, the number of tubes formed in the miR-335 mimics group was markedly lower than in the blank and miR-NC groups (Fig. 2D).

To further explore the role of miR-335 in the PC, we also successfully silenced the miR-335 expression in DU145 cells $(\mathrm{P}<0.01$; Fig. 3A). After being cultured for $>48 \mathrm{~h}$, the viability of DU145 cells was significantly enhanced in the miR-335 inhibitors group compared with the controls $(\mathrm{P}<0.01$; Fig. 3B). Additionally, the length of the tubes were significantly increased compared with the controls $(\mathrm{P}<0.01$; Fig. 3C and D) in miR-335 inhibitors group.

Role of miR-335 in the apoptosis of DU145 cells. miRNAs serve important roles in apoptosis; thus, the apoptosis of DU145 cells was analyzed in our study. A significant increase in the number of apoptotic cells was observed in the miR-335 mimics group, compared with the blank and miR-NC groups $(\mathrm{P}<0.01$; Fig. 4A). Whereas, the number of apoptotic cells in miR-335 inhibitors group exhibited no significant difference compared with the blank and miR-NC groups (Fig. 4B). The number of apoptotic DU145 cells was significantly increased in the miR-335 mimics group, compared with that in cells transfected with miR-335 inhibitors ( $\mathrm{P}<0.01$; Fig. 4C).

Furthermore, the number of caspase-3-positive cells markedly increased following iR-355 upregulation; a significant increase in activity of caspase-3 was observed in the miR-335 mimics group compared with the controls $(\mathrm{P}<0.01$; Fig. 5A and B). However, the proportion of caspase- 3 positive cells in the miR-335 inhibitors group was notably less than that in blank group or miR-NC group; caspase-3 activity was significantly reduced following miR-355 knockdown $(\mathrm{P}<0.01$; Fig. 5C and D).

Regulation of miR-335 in the expression of inflammatory cytokines. The protein expression levels of several pro-inflammatory factors, including IL-6, IL- 8 and IL- $1 \beta$ were significantly suppressed in the miR-335 mimics group compared with blank and miR-NC groups $(\mathrm{P}<0.01$; Fig. $6 \mathrm{~A})$. Similarly, the mRNA expression levels of IL-6, IL-8 and IL-1 $\beta$ in the miR-335 mimics group were significantly downregulated than in blank and miR-NC groups $(\mathrm{P}<0.01$; Fig. 6B). The protein expression levels of IL- 6 , IL- 8 and IL- $1 \beta$ were significantly enhanced following transfection with miR-335 inhibitors compared with the control groups $(\mathrm{P}<0.01$; Fig. $6 \mathrm{C})$; 
A

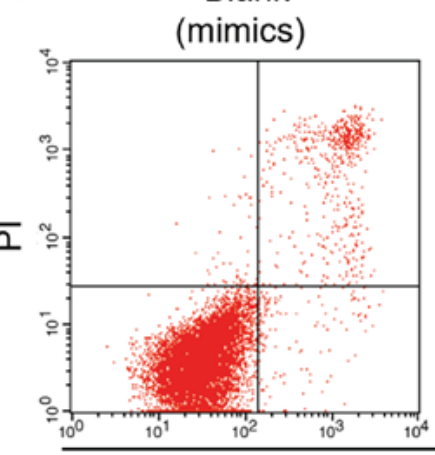

miR-NC (mimics)

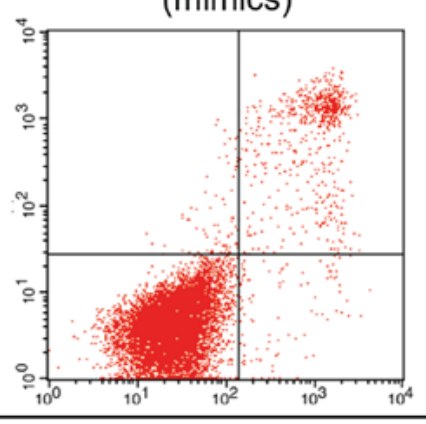

Annexin-V-FITC
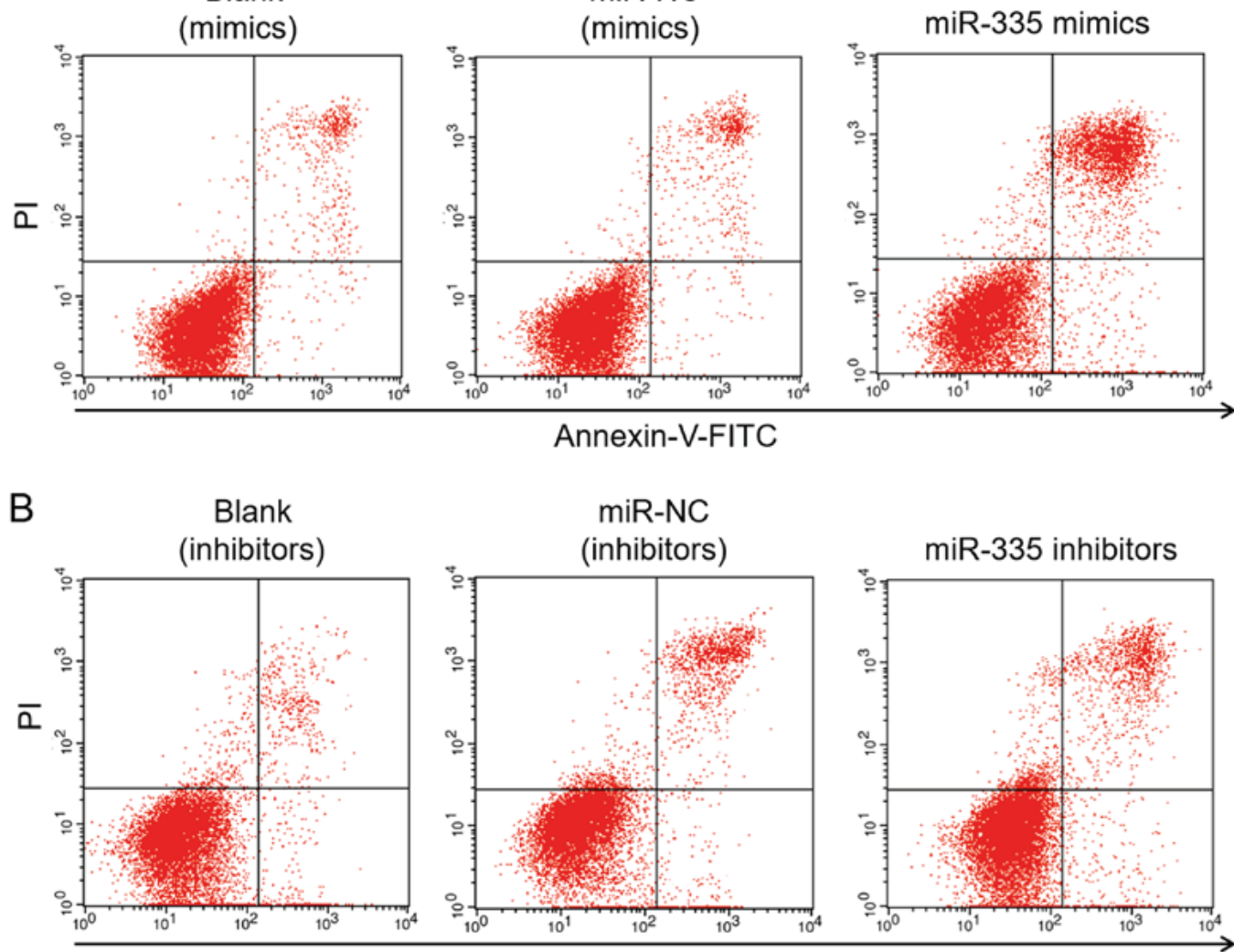

miR-NC

(inhibitors)

Blank

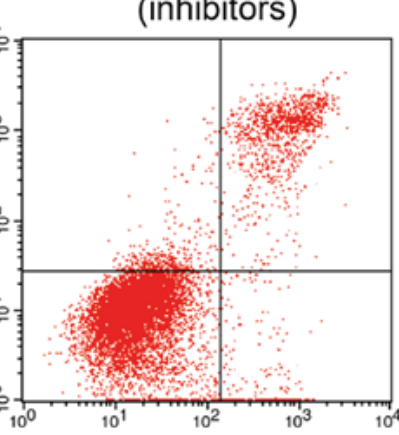

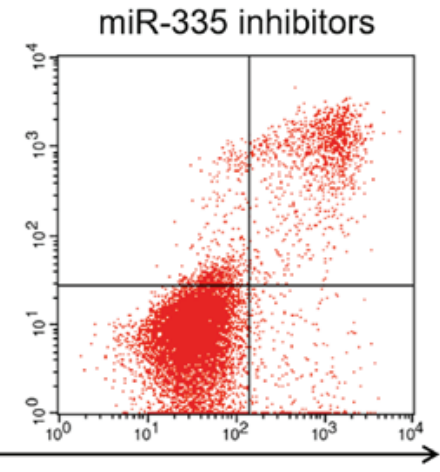

Annexin-V-FITC

C

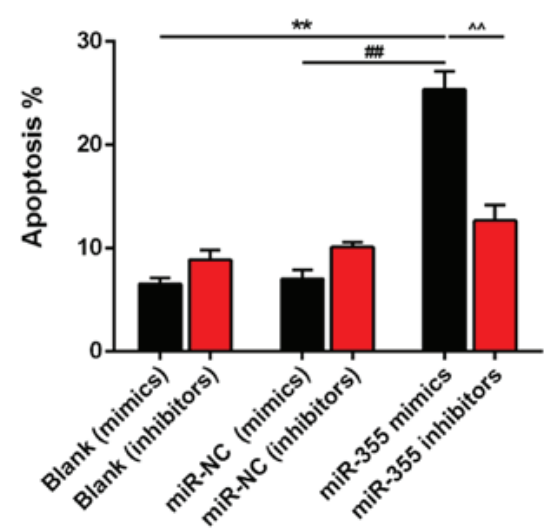

Figure 4. Effects of miR-335 on the apoptosis of DU145 cells. (A) The apoptotic cells in the blank, miR-NC and miR-335-mimics groups were determined by flow cytometry. (B) The apoptotic cells in the blank, miR-NC and miR-335-inhibitors groups were determined by flow cytometry. (C) Overexpression of miR-335 significantly promoted apoptosis, while miR-335 knockdown revealed no significant changes in apoptosis. ${ }^{* *} \mathrm{P}<0.01,{ }^{\# \#} \mathrm{P}<0.01,{ }^{\wedge} \mathrm{P}<0.01, \mathrm{n}=3$. miR, microRNA; NC, negative control.

a similar trend in mRNA expression was also for IL-6, IL-8 and IL-1 $\beta$ ( $\mathrm{P}<0.01$; Fig. 6D).

EGR3 is a potential target of miR-335. Based on the bioinformatic prediction analysis, a miR-335-binding site was mapped to the 3'-UTR of EGR3 (Fig. 7A). The luciferase activity in cells transfected with a wild-type EGR3-3' UTR vector containing miR-335 mimics was significantly reduced compared with the mutated 3'-UTR. However, the luciferase activity was significantly enhanced in DU145 cells transfected with wild-type EGR3-3'-UTR vector containing miR-335 inhibitors (Fig. 7B). EGR3 expression in miR-335 mimics group was significantly suppressed at the protein and
mRNA levels compared with the controls $(\mathrm{P}<0.01$; Fig. $7 \mathrm{C}$ and D). Conversely, the protein and mRNA expression levels of EGR3 were significantly increased in the cells transfected with miR-335 inhibitors compared with the controls $(\mathrm{P}<0.01$; Fig. 7E and F).

Roles of EGR3 in the PC cells. To understand the effects of EGR3 on prostate tumors, we detected the angiogenesis and apoptosis of the DU145 cells. EGR3 expression was significantly knocked down at the transcription and translation levels in cells following transfection with siEGR3 $(\mathrm{P}<0.01$; Fig. 8A and B). Cell viability was significantly decreased following EGR3 knockdown in a time-dependent manner 

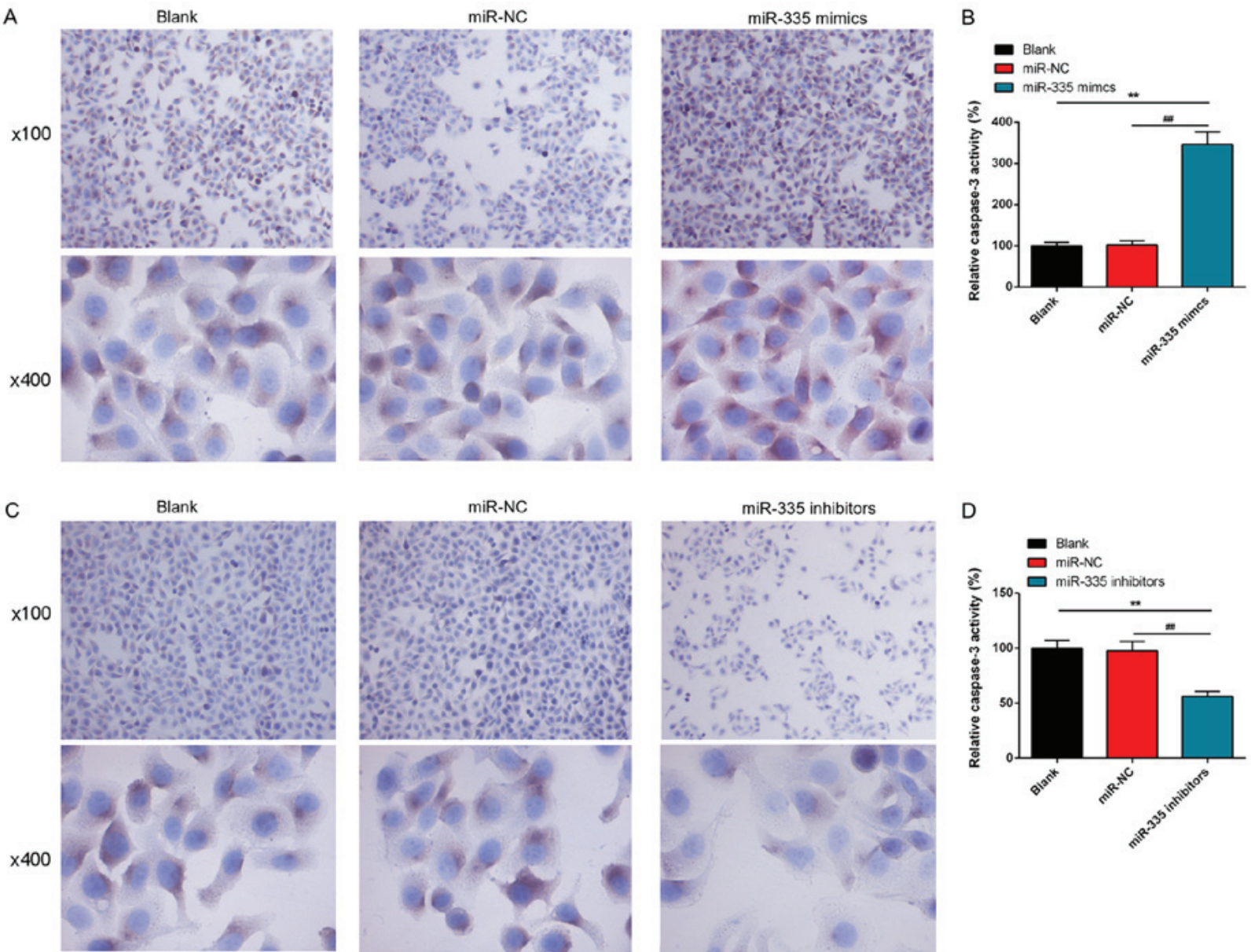

Figure 5. Effects of miR-335 on caspase-3 activity in DU145 cells. (A) Caspase-3-positive cells in the blank, miR-NC and miR-335-mimics groups were analyzed by immunocytochemistry. (B) The caspase-3 activity was significantly increased following miR-335 overexpression. (C) The caspase-3-positive cells in the blank, miR-NC and miR-335-inhibitors groups. (D) The caspase-3 activity was significantly reduced following downregulation of miR-335. ${ }^{* *} \mathrm{P}<0.01$, ${ }^{\# \#} \mathrm{P}<0.01, \mathrm{n}=3$. miR, microRNA; NC, negative control.

A
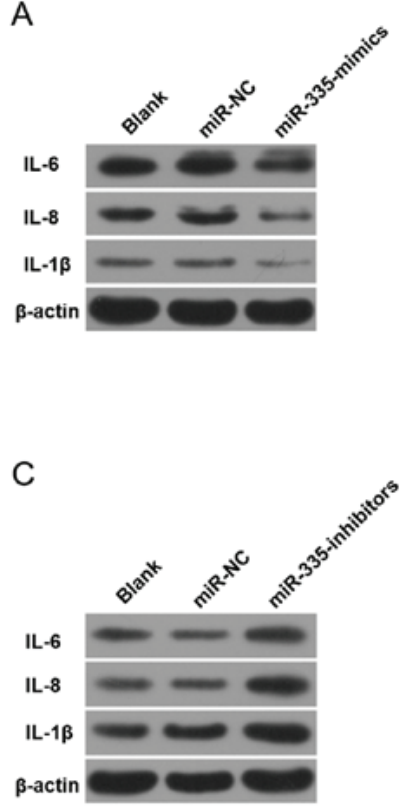
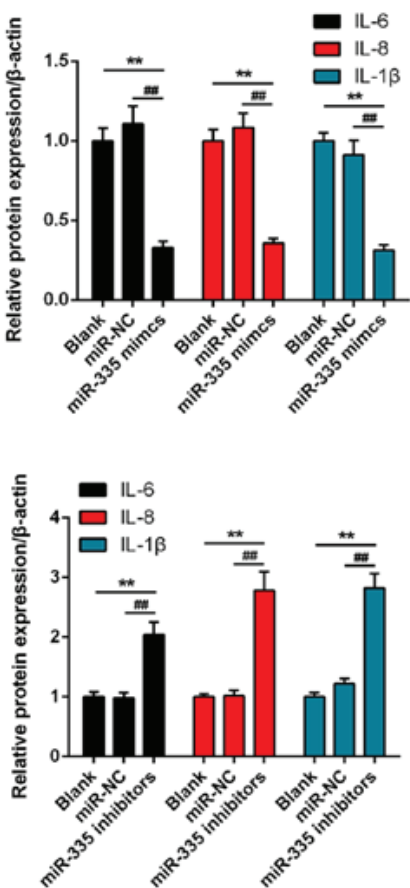

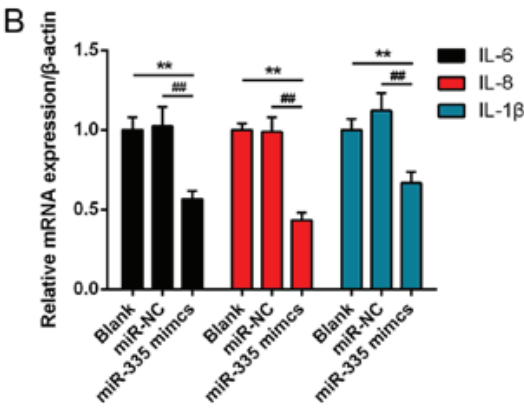

D

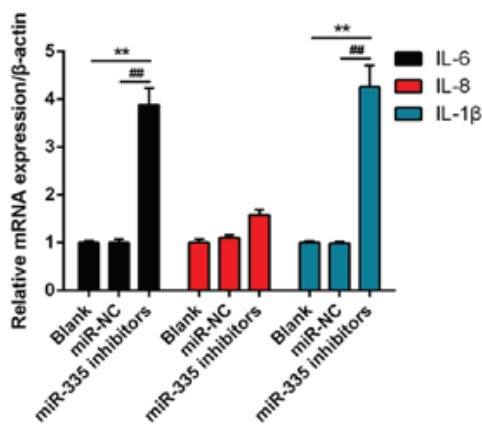

Figure 6. Effects of miR-335 on the expression of inflammatory cytokines in DU145 cells. (A and B) The protein and mRNA levels of IL-6, IL-8 and IL-1 $\beta$ were significantly reduced following miR-335 overexpression. (C and D) The protein and mRNA expression levels of IL-6, IL-8 and IL-1 $\beta$ were significantly enhanced following transfection with miR-335 inhibitors. ${ }^{* *} \mathrm{P}<0.01,{ }^{\# \#} \mathrm{P}<0.01, \mathrm{n}=3$. IL, interleukin; miR, microRNA; NC, negative control. 
A

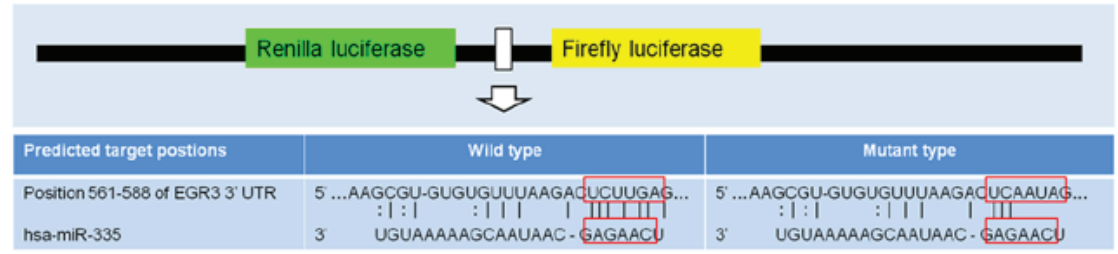

B

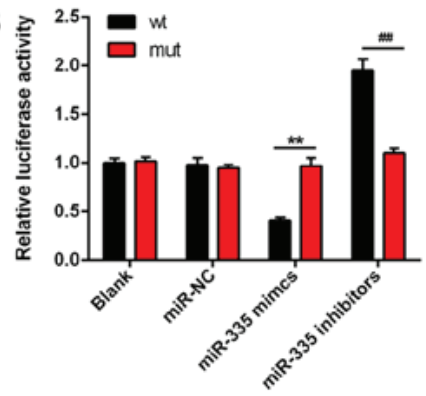

C
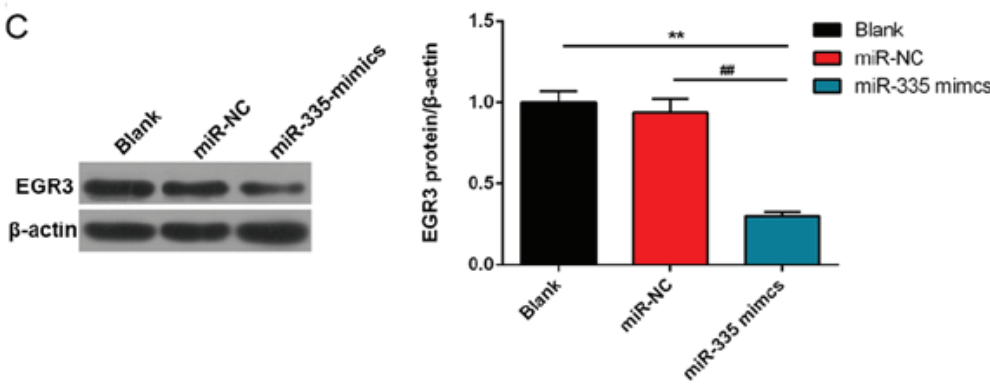

$\mathrm{E}$

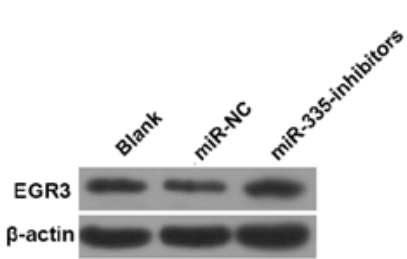

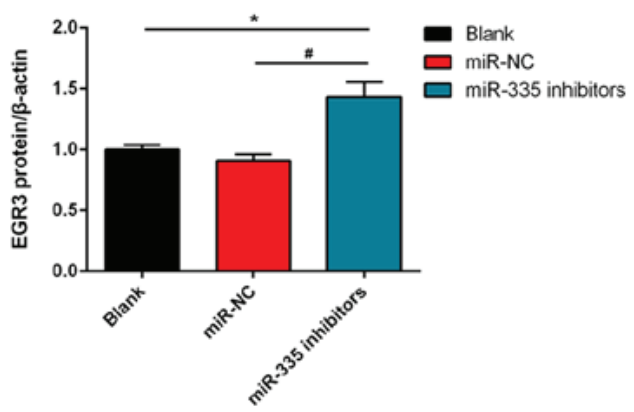
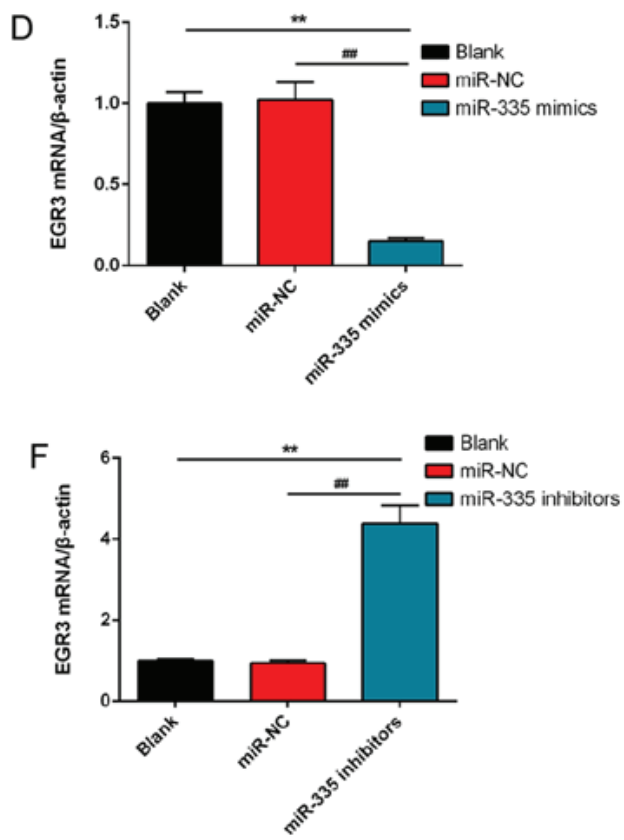

Figure 7. EGR3 is a potential target gene of miR-335. (A) EGR3 had a miR-335-binding site mapped to its 3 '-UTR. (B) The effects of miR-335 mimics and miR-335 inhibitors on the luciferase activities of DU145 cells transfected with EGR3-wt 3'- UTR vector or EGR3-mut 3'-UTR. (C and D) EGR3 expression was significantly reduced in the miR-335 mimics group at protein and mRNA levels. (E and F) Protein and mRNA expression levels of EGR3 were significantly enhanced in the miR-335 inhibitors group. ${ }^{*} \mathrm{P}<0.05,{ }^{* *} \mathrm{P}<0.01,{ }^{\#} \mathrm{P}<0.05,{ }^{\# \#} \mathrm{P}<0.01, \mathrm{n}=3$. EGR3, early growth response 3 ; miR, microRNA; mut, mutant; NC, negative control; 3'-UTR, 3'-untranslated region; wt, wild-type.

compared with the controls $(\mathrm{P}<0.01$; Fig. $8 \mathrm{C})$. In addition, the number of regenerative vessels were notably reduced in siEGR3 group, and the tube length was significantly decreased compared with the controls ( $\mathrm{P}<0.01$; Fig. 8D and E). Following transfection with siEGR3, the number of apoptotic cells was significantly elevated compared with the control cells $(\mathrm{P}<0.01$; Fig. 8F and G). Furthermore, the number of caspase- 3 positive cells markedly increased following transfection with siEGR3 (Fig. 9A). Correspondingly, caspase-3 activity was significantly promoted in the siEGR3 group compared with the controls $(\mathrm{P}<0.01$; Fig. 9B). Additionally, the protein and mRNA expression levels of IL-6, IL-8 and IL-1 $\beta$ were significantly suppressed in the siEGR3 group compared with the controls $(\mathrm{P}<0.01$; Fig. 9C and D). The viability of cells was significantly increased after miR-335 knockdown compared with cells transfected with miR-355 inhibitors and siEGR3, of which the viability was notably higher than those in non-transfected cells, and cells transfected with miR-NC or siNC ( $\mathrm{P}<0.05$; Fig. 9E).

miR-335 inhibits the formation of PC solid tumor in vivo. In order to explore the effects of miR-335 on the tumorigenicity of PC, nude mice were transplanted with PC-3M or DU145 cells to establish PC models in vivo. The results revealed that the mRNA expression levels of miR-335 were significantly upregulated in PC-3M and DU145 cells compared with the controls $(\mathrm{P}<0.01$; Fig. 10A). The tumor weight and volume exhibited no significant differences between the blank and miR-NC groups; however, when mice were transplanted with PC-3M + miR-335 mimic or DU145 + miR-335 mimic, the weight and volume of tumors were significantly reduced $(\mathrm{P}<0.01$ and $\mathrm{P}<0.05$, respectively; Fig. 10B-E). IHC staining demonstrated that EGR3 was positively expression in the blank and $\mathrm{NC}$ groups; tissues expressing miR-335 mimic exhibited significantly downregulated EGR3 protein expression $(\mathrm{P}<0.01$; Fig. 10F and G). The results indicated that miR-335 inhibited the formation of PC solid tumor possibly by decreasing the expression of EGR3.

\section{Discussion}

miRNAs can regulate numerous genes atthe post-transcriptional level, and the aberrant expression of miRNAs is closely associated with the development of neoplasms in humans (36). Recently, a substantial number of cancer-specific miRNAs 
A
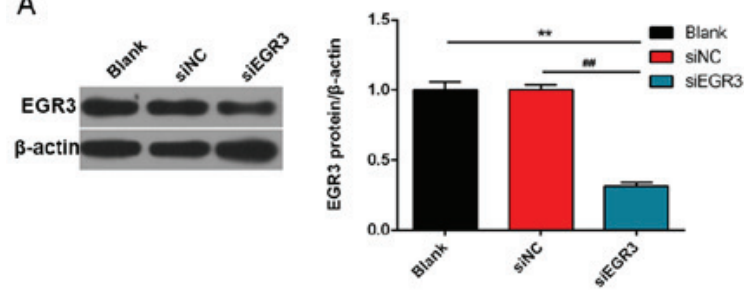

D
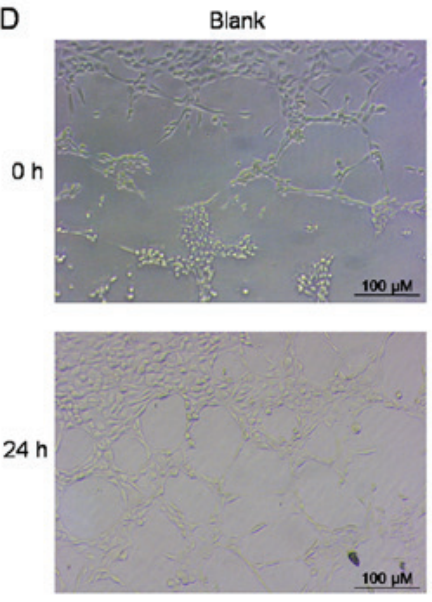

$\mathrm{F}$

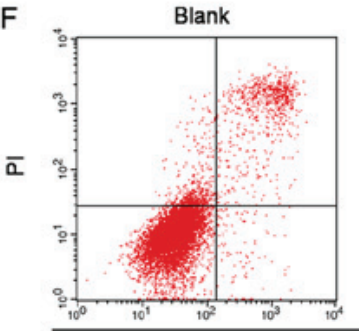

siNC
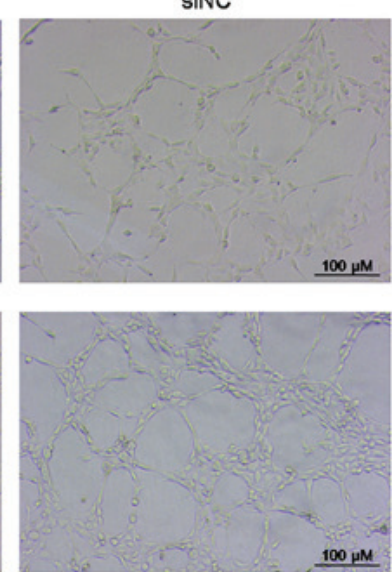

$100 \mu \mathrm{M}$

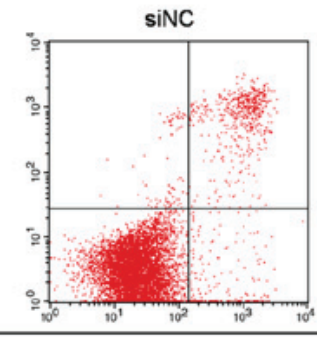

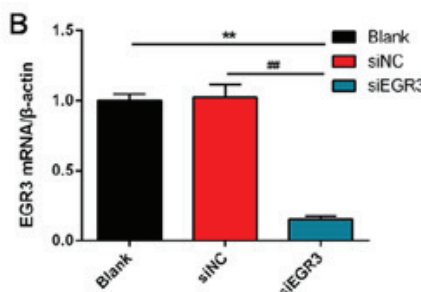

siEGR3
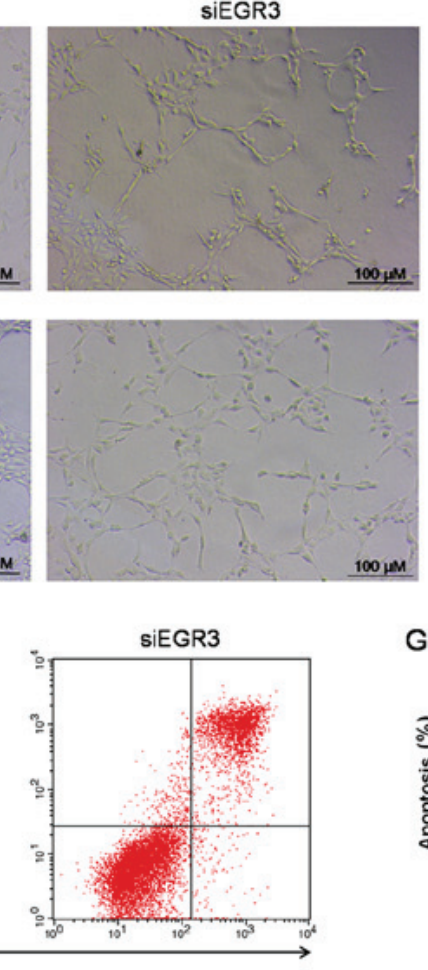

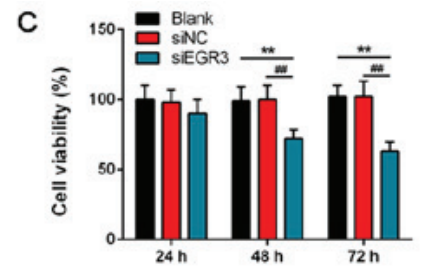

E
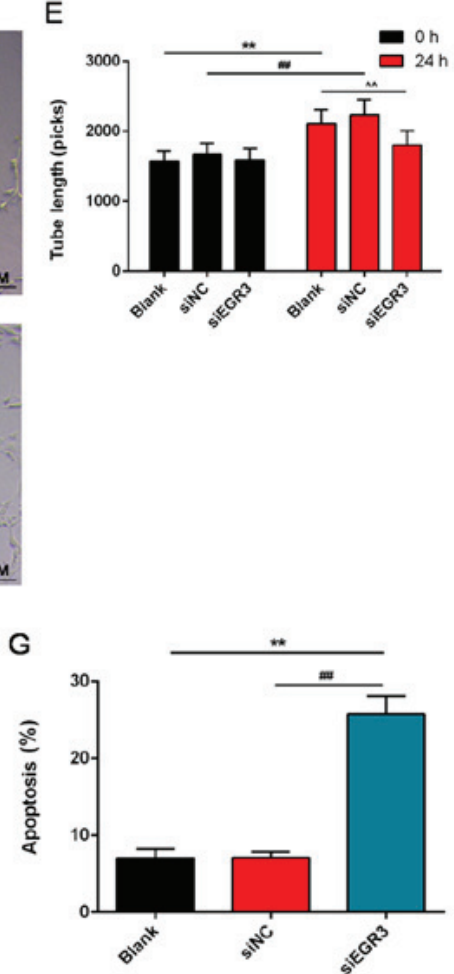

Figure 8. Role of EGR3 in cell viability, angiogenesis and apoptosis. (A and B) The expression of EGR3 was successfully knocked down at protein and mRNA levels following transfection with siEGR3. (C) Cell viability was significantly inhibited by the knockdown EGR3. (D and E) The length and number of tubes of HUVECs were reduced in siEGR3 group. ( $\mathrm{F}$ and $\mathrm{G})$ Apoptosis was significantly promoted by silencing EGR3 expression. Scale bar $=100 \mu$ m. ${ }^{* *} \mathrm{P}<0.01$, ${ }^{\# \#} \mathrm{P}<0.01,{ }^{\wedge} \mathrm{P}<0.01, \mathrm{n}=3$. EGR3, early growth response 3; NC, negative control; si, small interfering RNA.

have been identified as tumor biomarkers in various types of cancer $(37,38)$. Several miRNAs, including miR-1, miR-133a, miR-143 and miR-145 were reported to inhibit tumor development by targeting oncogenic genes in PC (39-41). EGR3, a member of zinc finger transcription factors, was demonstrated to be involved in angiogenesis, inflammation and neurodevelopment (42-44). Furthermore, it was revealed that EGR3 is involved in the occurrence and development of numerous types of cancers, and that EGR3 may be regarded as a tumor suppressor in various cancers $(30,35,45)$. In the study, we demonstrated that miR-335 expression was downregulated, while EGR3 expression was enhanced in PC tissues. Additionally, miR-335 suppressed cell viability, angiogenesis and inflammation, and promoted the apoptosis of PC cells. In vivo miR-355 inhibited the formation of $\mathrm{PC}$ solid tumor. We also reported that EGR3 could be a potential target of miR-335 and inhibition of EGR3 inhibited the tumorigenesis of a xenograft $\mathrm{PC}$ in vivo.

Downregulated miR-335 expression has been reported in many types of cancer, such as BCa, acute myeloid leukemia, gastric cancer and adrenocortical carcinomas (16,46-48). In the present study, the miR-335 expression was significantly reduced in the tissues of patients with $\mathrm{PC}$, indicating that miR-335 may serve a vital role in tumorigenesis (49). The malignant transformation of normal cells is a multilevel and intricate process that is associated with hereditary and epigenetic changes (50). Oncogenes and tumor-suppressor genes could be closely related to proliferation and/or apoptosis; transformed cells may possess anti-apoptosis, invasive, and/or metastatic properties, thus leading to tumorigenesis (51). In addition, miR-335 can function as a tumor suppressor by inhibiting proliferation and inducing apoptosis in various cancer types. For instance, miR-335 expression is reduced in BCa tissues, blood and cells; and miR-335 regulates the viability and apoptosis of cells by targeting the upstream genes of BRCA1 in BCa $(23,24)$. Furthermore, elevated miR-335 expression inhibits the proliferation and mammosphere formation of BCa stem-like cells (52). Overexpression of miR-335 can also reduce cell viability by inhibiting rho-associated, coiled-coil-containing 1 expression in hepatocellular carcinoma cells (53), and can promote apoptosis by targeting specificity protein 1 and BCL-w in lung cancer (54). Furthermore, miR-335 can also suppress cell viability and induce apoptosis by targeting members of 
A

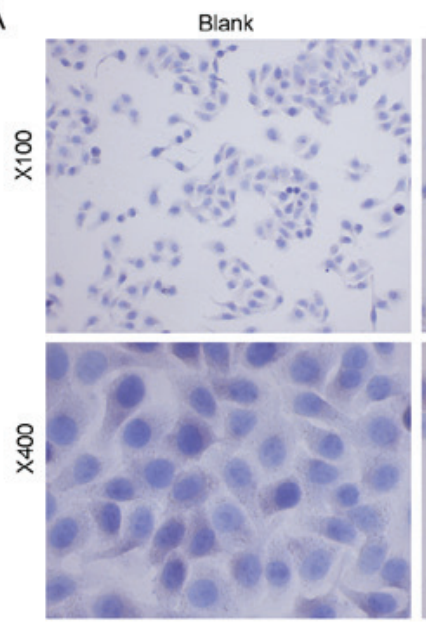

C

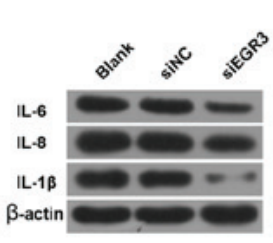

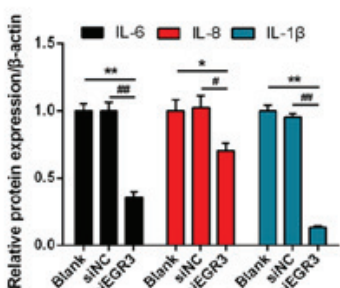
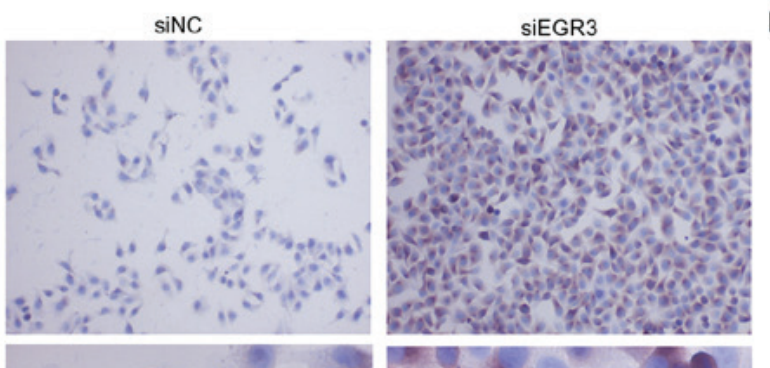

B
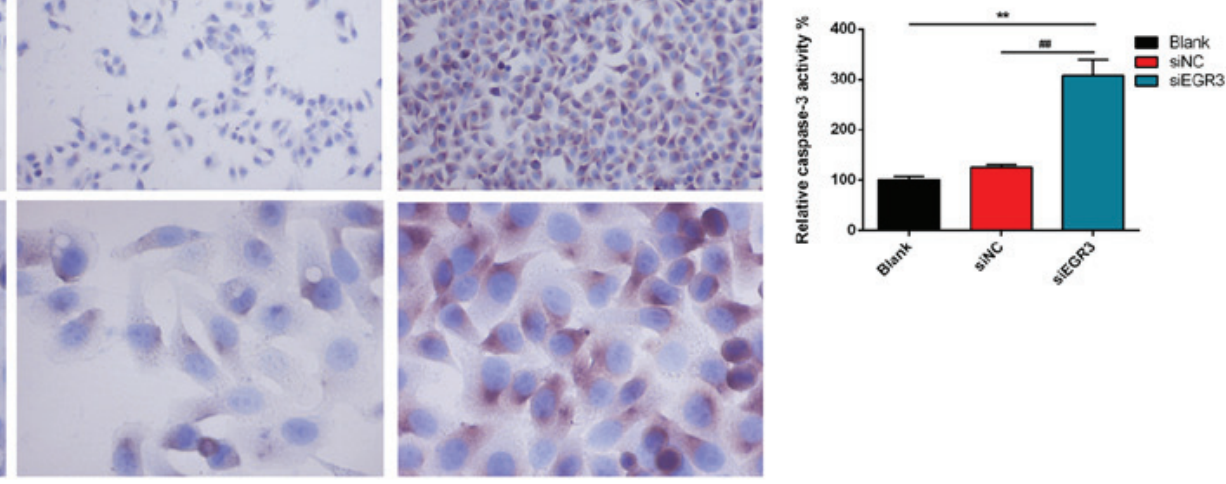

D

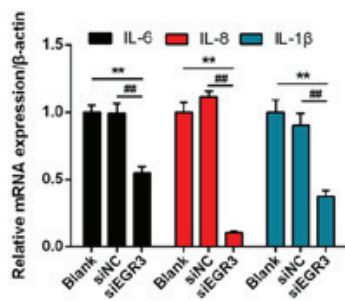

E

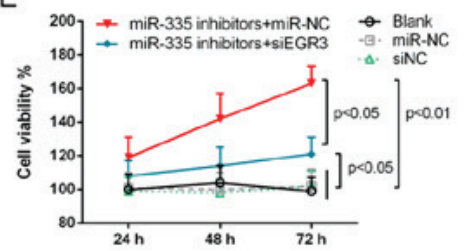

Figure 9. miR-335 exhibits anticancer effects by regulating EGR3 in DU145 cells. (A and B) Caspase-3 activity was significantly enhanced by silencing EGR3 expression. Magnifications, $x 200$ and 400. (C and D) The protein and mRNA expression levels of IL-6, IL-8 and IL-1 $\beta$ were significantly inhibited by downregulating EGR3. (E) miR-335 inhibitors suppressed the viability of cells following the downregulation of EGR $3 .{ }^{*} \mathrm{P}<0.05,{ }^{* *} \mathrm{P}<0.01,{ }^{\sharp} \mathrm{P}<0.05,{ }^{\# \#} \mathrm{P}<0.01$, $\mathrm{n}=3$. EGR3, early growth response 3; IL, interleukin; miR, microRNA; NC, negative control; si, small interfering RNA.

the inhibitors of apoptosis protein family IAP; miR-335 can regulate the cell cycle and the apoptotic pathways in gastric cancer (55). miR-335 can initiate the p53 pathway to inhibit cell proliferation by targeting the 3'-UTR of retinoblastoma 1 , and increased proliferation caused by impaired p53 signaling has been linked to increased miR-335 levels, suggesting that the regulation of cell viability by miR-335 may be dependent on p53 (56). Apoptosis is relevant to various pathological processes, and the cells which evade apoptosis are involved in tumorigenesis (25). miR-335 was reported as a proapoptotic miRNA (57); low miR-335 expression can result in the proliferation and migration of mesenchymal stem cells (58). Additionally, inflammation is one of the indicators of cancer and exerts a crucial effect on tumor development $(59,60)$. A previous study indicated that miR-335 may be involved in the IL-6/JNK2/STAT3 pathway (61). We observed that overexpression of miR-335 could inhibit the viability and angiogenesis, and promote the apoptosis of PC cells and reduce the expression of inflammatory cytokines. In addition, we also silenced the expression of miR-335, and found that the inhibition of miR-335 could exert opposing effects on than miR-335 overexpression. These results confirmed that miR-335 could function as a potential tumor suppressor of PC (62).

miR-335 regulates numerous target genes involved in the progression of cancers (14). In the present study, EGR3 was identified as a candidate target gene of miR-335 based on bioinformatics analysis. Furthermore, the dual-luciferase assay also suggested that EGR3 was a potential target of miR-335 and was negatively regulated by miR-335 in PC cells. A previous study reported reduced EGR3 expression in gastric cancer tissues, which was associated with adverse prognosis (35); however, EGR3 overexpression increased cell invasion in BCa (63), suggesting that EGR3 may serve complicated roles in a tumor-specific manner. Of note, we demonstrated that EGR3 expression was enhanced in PC tissues, which was inversely correlated with the expression of miR-335. This suggested that EGR3 may serve a potential role in PC. Furthermore, EGR3 can mediate multiple biological processes (64). EGR3 was revealed to be involved in angiogenesis, inflammation and cancer $(32,65)$. It has been reported that IL-6 can result in enhanced proliferation and epithelial-mesenchymal transition of PC cells (66). In addition, IL-8 silencing increased apoptosis, induced cell cycle arrest and improve chemotherapeutic outcomes of PC cells (67). In the present study, we reduced the expression of EGR3 in DU145 cells, and observed that the knockdown of EGR3 inhibited the viability and angiogenesis, promoted apoptosis and decreased the expression of inflammatory cytokines in these cells. The results were related to suppressed cell viability, as reported with miR-335 overexpression. Furthermore, we synchronously inhibited the expression of miR-335 and EGR3, and found that the viability of cells was reduced, indicating that miR-335 inhibited cell viability by targeting the EGR3.

In this study, there were some limitations. For instance, more cell lines are required to validate the presented data; more groups could also be established to demonstrate the targeting of miR-355 to EGR3. We aim to conduct more detailed and comprehensive experiments in the future, using certain groups: miR-355 mimics + EGR3 [wild-type (wt)], miR-355 mimics + EGR3 (mutant), miR-355 inhibitors + EGR3 (wt), miR-355 inhibitor + EGR3 (mutant) and another cell line.

In conclusion, miR-335 decreased cell viability and angiogenesis, suppressed inflammatory-marker expression 
A
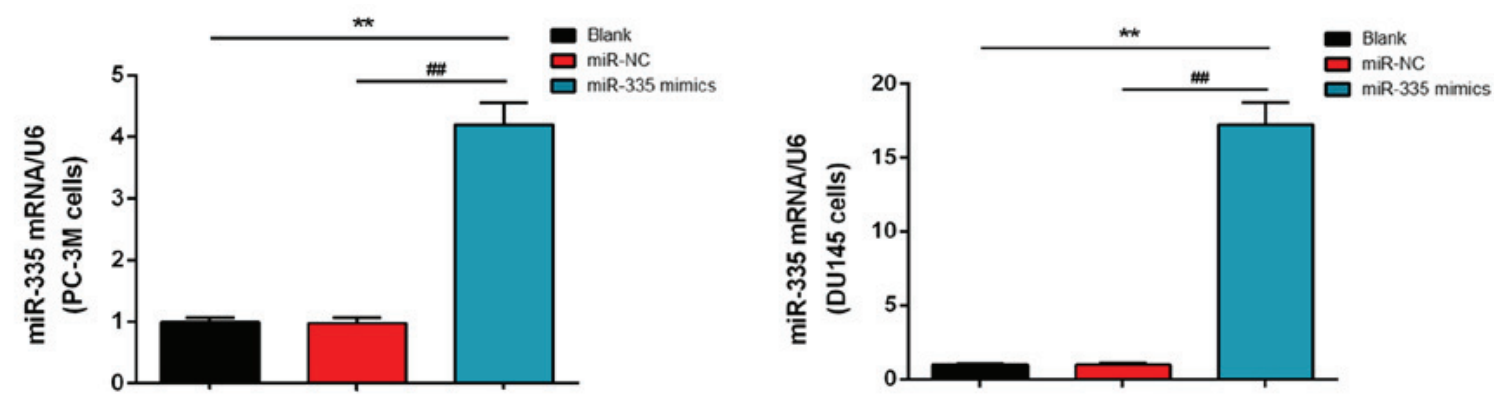

B
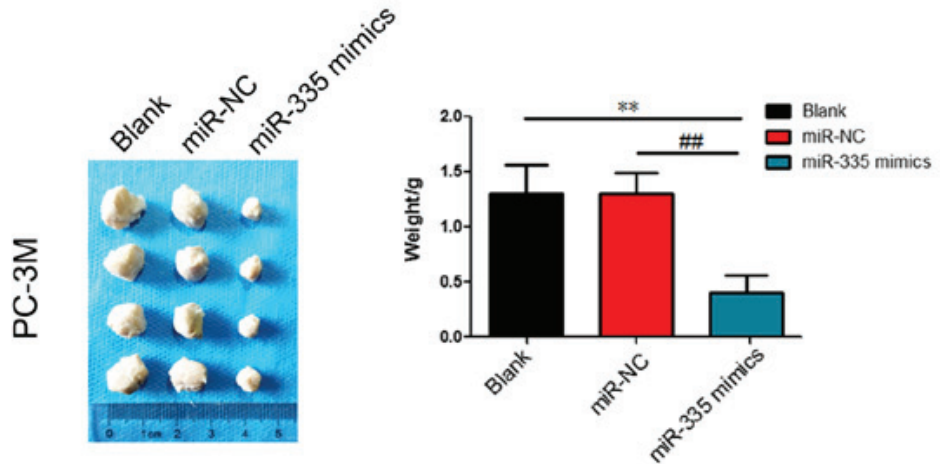

C
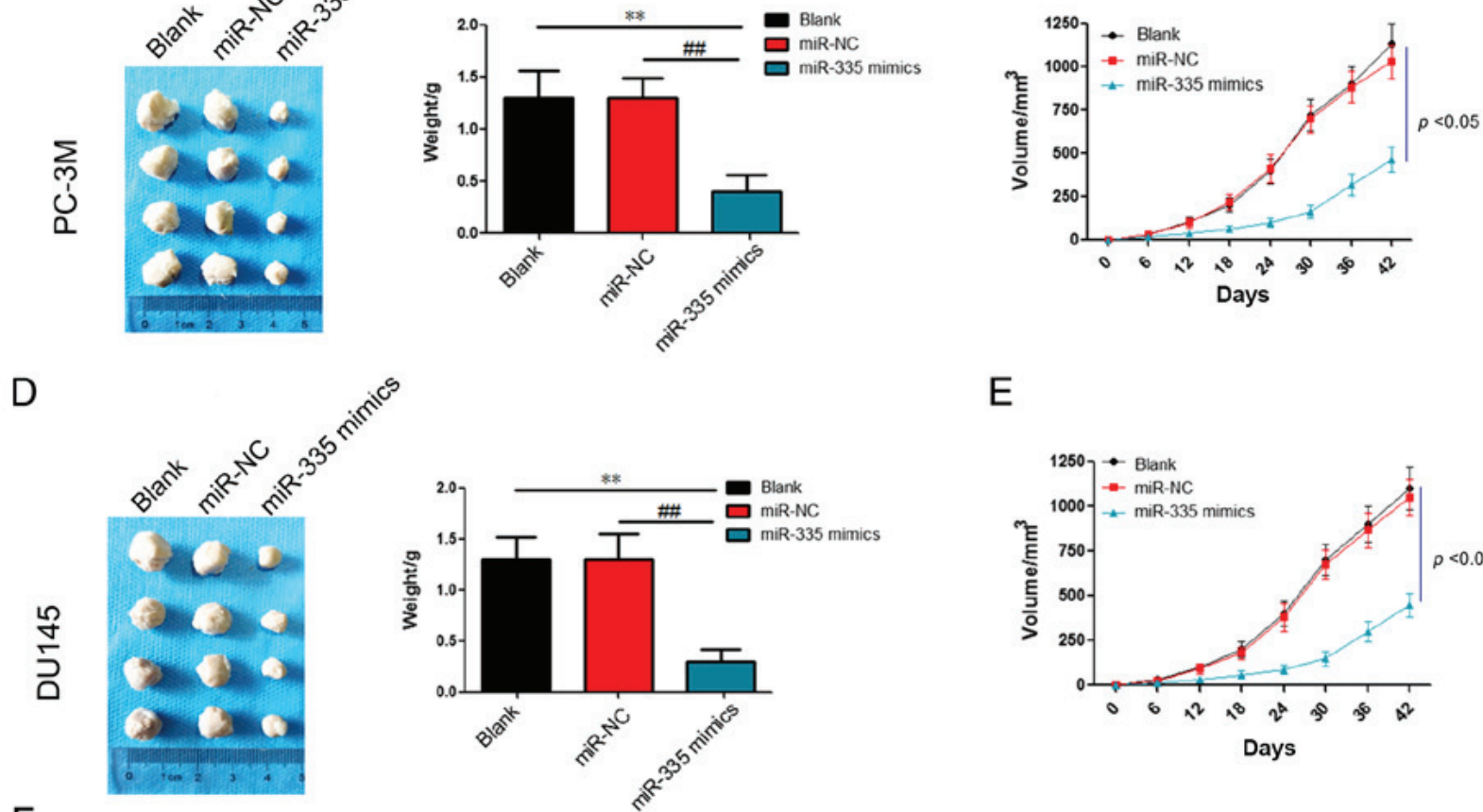

E

$\mathrm{F}$

Blank

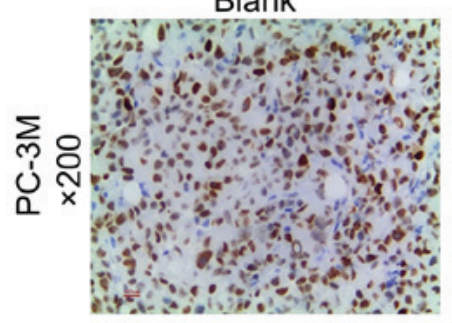

miR-NC

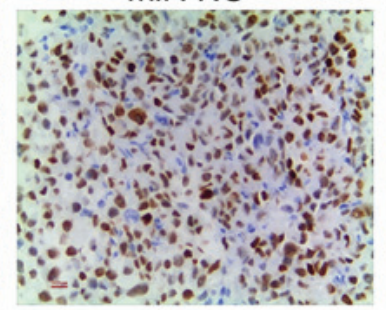

miR-NC

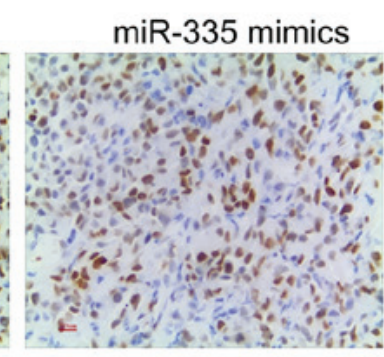

miR-335 mimics
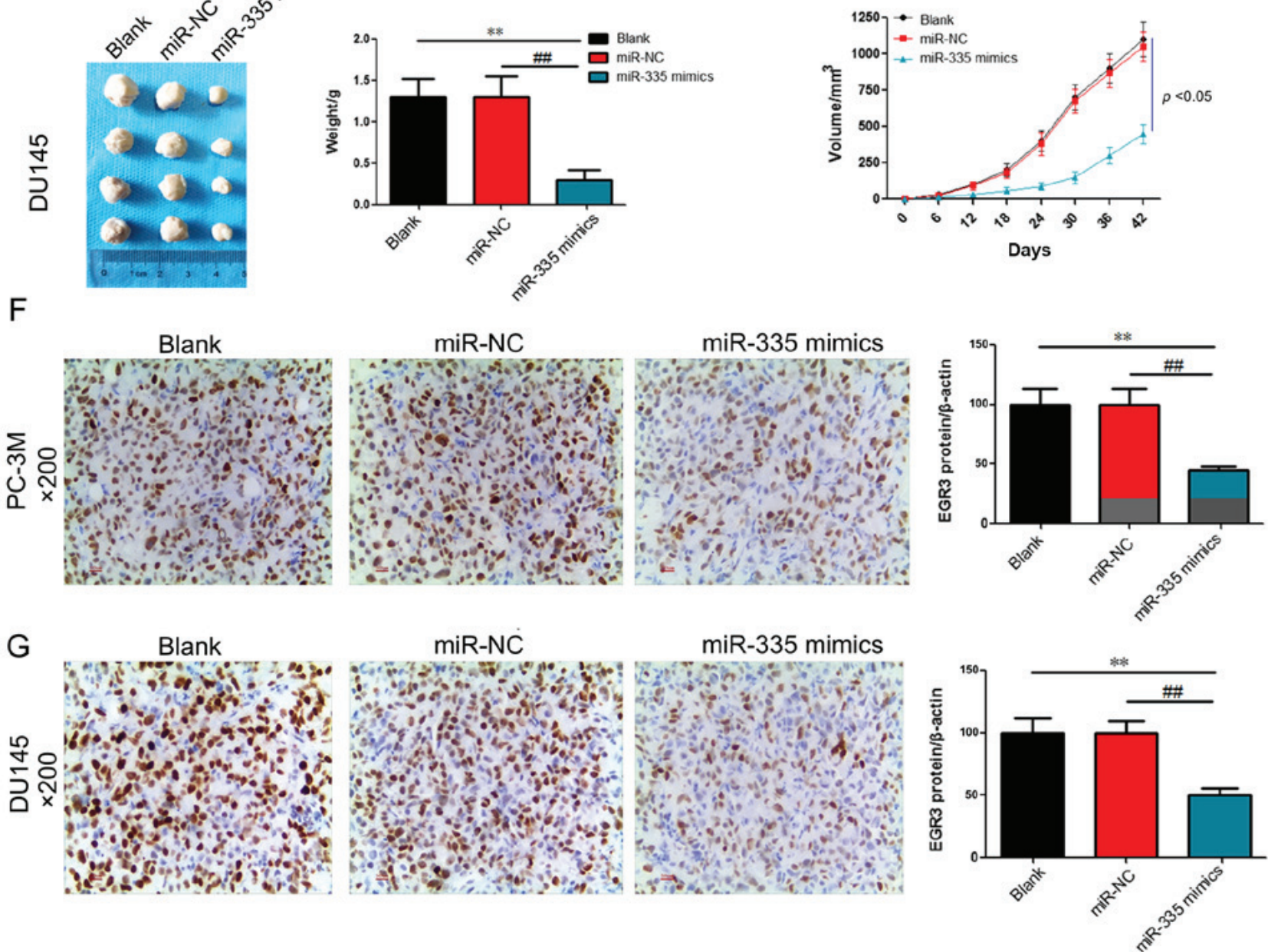

Figure 10. miR-335 inhibits the formation of PC solid tumor by regulating EGR3 expression in vivo. A xenograft mouse model of prostate cancer was generated by a hypodermic injection of $5 \times 10^{6}$ cells into the lateral abdominal wall of mice. PC-3M-derived tumors were collected out 42 days after administration. (A) miR-335 expression was successfully upregulated in the xenograft tumors of in PC-3M and DU145 cells expressing miR-355 mimics. (B) Tumor weight and (C) volume in PC-3M cells were quantified. DU145-derived tumors were collected 42 days after the administration of cells. (D) Tumor weight and (E) volume in DU145 cells were quantified. Immunohistochemistry staining was performed to analyze EGR3 protein expression in (F) PC-3M-derived tumors tissues and (G) DU145-derived tumors tissues. Magnification, $x 200$. $\beta$-actin served as an internal control. Data were expressed as mean \pm standard deviation from three independent experiments. ${ }^{* *} \mathrm{P}<0.05,{ }^{\# /} \mathrm{P}<0.05$. EGR3, early growth response 3 ; miR, microRNA; NC, negative control. 
and promoted apoptosis by targeting the EGR3 in PC cells These findings suggested that miR-335 is closely associated with the initiation and progression of cancer, and may act as a potential biomarker in the treatment of patients with PC.

\section{Acknowledgements}

Not applicable.

\section{Funding}

No funding was received.

\section{Availability of data and materials}

The analyzed data sets generated during the study are available from the corresponding author on reasonable request.

\section{Authors' contributions}

PZ and XY made substantial contributions to conception and design of the present study. LW and DZ conducted data acquisition, data analysis and interpretation. PZ drafted the article and critically revised it for important intellectual content. All authors approved for the final version to be published. BW and QL agreed to be accountable for all aspects of the work in ensuring that questions related to the accuracy or integrity of the work are appropriately investigated and resolved. All authors read and approved the final manuscript.

\section{Ethics approval and consent to participate}

The present study was approved by the Ethics Committee of The Second Affiliated Hospital of Xi'an Jiaotong University

\section{Patient consent for publication}

Not applicable.

\section{Competing interests}

The authors declare no conflicts of interest.

\section{References}

1. Xiao W, Dai B, Zhu Y and Ye D: Norcantharidin induces autophagy-related prostate cancer cell death through Beclin-1 upregulation by miR-129-5p suppression. Tumour Biol: Dec 5, 2015 (Epub ahead of print).

2. Siegel R, Naishadham D and Jemal A: Cancer statistics, 2012 CA Cancer J Clin 62: 10-29, 2012.

3. Utomo NB, Mochtar CA and Umbas R: Primary hormonal treatment in localized and locally advanced prostate cancer: Effectiveness and survival predictive factors. Acta Med Indones 44: 10-15, 2012.

4. Dasgupta S, Srinidhi S and Vishwanatha JK: Oncogenic activation in prostate cancer progression and metastasis: Molecular insights and future challenges. J Carcinog 11: 4, 2012.

5. Fraser M, Berlin A, Bristow RG and van der Kwast T: Genomic, pathological, and clinical heterogeneity as drivers of personalized medicine in prostate cancer. Urol Oncol 33: 85-94, 2015.

6. Fabris L, Ceder Y, Chinnaiyan AM, Jenster GW, Sorensen KD, Tomlins S, Visakorpi T and Calin GA: The potential of microRNAs as prostate cancer biomarkers. Eur Urol 70: 312-322, 2016.
7. Porkka KP,Pfeiffer MJ, Waltering KK, Vessella RL, Tammela TL and Visakorpi T: MicroRNA expression profiling in prostate cancer. Cancer Res 67: 6130-6135, 2007.

8. Srivastava A, Goldberger H, Dimtchev A, Ramalinga M, Chijioke J, Marian C, Oermann EK, Uhm S, Kim JS, Chen LN, et al: MicroRNA profiling in prostate cancer - the diagnostic potential of urinary miR-205 and miR-214. PLoS One 8: e76994, 2013.

9. Shi XB, Xue L, Yang J, Ma AH, Zhao J, Xu M, Tepper CG Evans CP, Kung HJ and deVere White RW: An androgen-regulated miRNA suppresses Bak1 expression and induces androgen-independent growth of prostate cancer cells. Proc Natl Acad Sci USA 104: 19983-19988, 2007.

10. Hsu TI, Hsu CH, Lee KH, Lin JT, Chen CS, Chang KC, Su CY, Hsiao M and Lu PJ: MicroRNA-18a is elevated in prostate cancer and promotes tumorigenesis through suppressing STK4 in vitro and in vivo. Oncogenesis 3: e99, 2014.

11. Wang L, Li B, Li L and Wang T: MicroRNA-497 suppresses proliferation and induces apoptosis in prostate cancer cells. Asian Pac J Cancer Prev 14: 3499-3502, 2013.

12. Nazarov PV, Reinsbach SE, Muller A, Nicot N, Philippidou D, Vallar L and Kreis S: Interplay of microRNAs, transcription factors and target genes: Linking dynamic expression changes to function. Nucleic Acids Res 41: 2817-2831, 2013.

13. Cellini F, Morganti AG, Genovesi D, Silvestris N and Valentini V: Role of microRNA in response to ionizing radiations: Evidences and potential impact on clinical practice for radiotherapy. Molecules 19: 5379-5401, 2014.

14. Luo LJ, Wang DD, Wang J, Yang F and Tang JH: Diverse roles of miR-335 in development and progression of cancers. Tumour Biol 37: 1-12, 2016.

15. Tavazoie SF, Alarcón C, Oskarsson T, Padua D, Wang Q, Bos PD, Gerald WL and Massagué J: Endogenous human microRNAs that suppress breast cancer metastasis. Nature 451: 147-152, 2008.

16. Wang F, Zheng Z, Guo J and Ding X: Correlation and quantitation of microRNA aberrant expression in tissues and sera from patients with breast tumor. Gynecol Oncol 119: 586-593, 2010.

17. Sorrentino A, Liu CG, Addario A, Peschle C, Scambia G and Ferlini C: Role of microRNAs in drug-resistant ovarian cancer cells. Gynecol Oncol 111: 478-486, 2008.

18. Shu M, Zheng X, Wu S, Lu H, Leng T, Zhu W, Zhou Y, Ou Y, Lin X, Lin Y, et al: Targeting oncogenic miR-335 inhibits growth and invasion of malignant astrocytoma cells. Mol Cancer 10: 59, 2011.

19. Dohi O, Yasui K, Gen Y, Takada H, Endo M, Tsuji K, Konishi C, Yamada N, Mitsuyoshi H, Yagi N, et al: Epigenetic silencing of miR-335 and its host gene MEST in hepatocellular carcinoma. Int J Oncol 42: 411-418, 2013.

20. Shi L, Jiang D, Sun G, Wan Y, Zhang S, Zeng Y, Pan T and Wang Z: miR-335 promotes cell proliferation by directly targeting Rb1 in meningiomas. J Neurooncol 110: 155-162, 2012.

21. Fu Q, Liu X, Liu Y, Yang J, Lv G and Dong S: MicroRNA-335 and -543 suppress bone metastasis in prostate cancer via targeting endothelial nitric oxide synthase. Int J Mol Med 36: 1417-1425, 2015.

22. Sun Z, Zhang Z, Liu Z, Qiu B, Liu K and Dong G; Z S: MicroRNA-335 inhibits invasion and metastasis of colorectal cancer by targeting ZEB2. Med Oncol 31: 982, 2014.

23. Heyn H, Engelmann M, Schreek S, Ahrens P, Lehmann U, Kreipe H, Schlegelberger B and Beger C: MicroRNA miR-335 is crucial for the BRCA1 regulatory cascade in breast cancer development. Int J Cancer 129: 2797-2806, 2011.

24. Gao Y, Zeng F, Wu JY, Li HY, Fan JJ, Mai L, Zhang J, Ma DM, Li Y and Song FZ: miR-335 inhibits migration of breast cancer cells through targeting oncoprotein c-Met. Tumour Biol 36: 2875-2883, 2015

25. Zhang S, Xia C, Xu C, Liu J, Zhu H, Yang Y, Xu F, Zhao J, Chang Y and Zhao Q: Early growth response 3 inhibits growth of hepatocellular carcinoma cells via upregulation of Fas ligand. Int J Oncol 50: 805-814, 2017.

26. Bhattacharyya S, Fang F, Tourtellotte W and Varga J: Egr-1: New conductor for the tissue repair orchestra directs harmony (regeneration) or cacophony (fibrosis). J Pathol 229: 286-297, 2013.

27. Bolli N, Avet-Loiseau H, Wedge DC, Van Loo P, Alexandrov LB, Martincorena I, Dawson KJ, Iorio F, Nik-Zainal S, Bignell GR, et al: Heterogeneity of genomic evolution and mutational profiles in multiple myeloma. Nat Commun 5: 2997, 2014.

28. Boone DN, Qi Y, Li Z and Hann SR: Egr1 mediates p53-independent c-Myc-induced apoptosis via a noncanonical ARF-dependent transcriptional mechanism. Proc Natl Acad Sci USA 108: 632-637, 2011. 
29. Wirth M, Stojanovic N, Christian J, Paul MC, Stauber RH, Schmid RM, Häcker G, Krämer OH, Saur D and Schneider G: MYC and EGR1 synergize to trigger tumor cell death by controlling NOXA and BIM transcription upon treatment with the proteasome inhibitor bortezomib. Nucleic Acids Res 42: 10433-10447, 2014.

30. Salotti J, Sakchaisri K, Tourtellotte WG and Johnson PF: An Arf-Egr-C/EBP $\beta$ pathway linked to ras-induced senescence and cancer. Mol Cell Biol 35: 866-883, 2015.

31. Pio R, Jia Z, Baron VT and Mercola D; UCI NCI SPECS Consortium of the Strategic Partners for the Evaluation of Cancer Signatures-Prostate Cancer: Early growth response 3 (Egr3) is highly over-expressed in non-relapsing prostate cancer but not in relapsing prostate cancer. PLoS One 8: e54096, 2013

32. Baron VT, Pio R, Jia Z and Mercola D: Early growth response 3 regulates genes of inflammation and directly activates IL6 and IL8 expression in prostate cancer. Br J Cancer 112: 755-764, 2015

33. Livak KJ and Schmittgen TD: Analysis of relative gene expression data using real-time quantitative PCR and the 2(-Delta Delta C(T)) Method. Methods 25: 402-408, 2001.

34. National Research Council: Guide for the Care and Use of Laboratory Animals. 8th edition. The National Academies Press, Washington, DC, 2011.

35. Liao F, Ji MY, Shen L, Qiu S, Guo XF and Dong WG: Decreased EGR3 expression is related to poor prognosis in patients with gastric cancer. J Mol Histol 44: 463-468, 2013.

36. Wang ZD, Qu FY, Chen YY, Ran ZS, Liu HY and Zhang HD: Involvement of microRNA-718, a new regulator of EGR3, in regulation of malignant phenotype of HCC cells. J Zhejiang Univ Sci B 18: 27-36, 2017.

37. Hu X, Schwarz JK, Lewis JS Jr, Huettner PC, Rader JS, Deasy JO, Grigsby PW and Wang X: A microRNA expression signature for cervical cancer prognosis. Cancer Res 70: 1441-1448, 2010.

38. Lin M, Chen W, Huang J, Gao H, Ye Y, Song Z and Shen X: MicroRNA expression profiles in human colorectal cancers with liver metastases. Oncol Rep 25: 739-747, 2011.

39. Fuse M, Nohata N, Kojima S, Sakamoto S, Chiyomaru T Kawakami K, Enokida H, Nakagawa M, Naya Y, Ichikawa T, et al: Restoration of miR-145 expression suppresses cell proliferation, migration and invasion in prostate cancer by targeting FSCN1. Int J Oncol 38: 1093-1101, 2011.

40. Kojima S, Chiyomaru T, Kawakami K, Yoshino H, Enokida H, Nohata N, Fuse M, Ichikawa T, Naya Y, Nakagawa M, et al: Tumour suppressors miR-1 and miR-133a target the oncogenic function of purine nucleoside phosphorylase (PNP) in prostate cancer. Br J Cancer 106: 405-413, 2012.

41. Kojima S, Enokida H, Yoshino H, Itesako T, Chiyomaru T, Kinoshita T, Fuse M, Nishikawa R, Goto Y, Naya Y, et al: The tumor-suppressive microRNA-143/145 cluster inhibits cell migration and invasion by targeting GOLM1 in prostate cancer. J Hum Genet 59: 78-87, 2014

42. Nishimura Y, Takizawa R, Koike S, Kinoshita A, Satomura Y, Kawasaki S, Yamasue H, Tochigi M, Kakiuchi C, Sasaki T, et al: Association of decreased prefrontal hemodynamic response during a verbal fluency task with EGR3 gene polymorphism in patients with schizophrenia and in healthy individuals. Neuroimage 85: 527-534, 2014.

43. Li S, Miao T, Sebastian M, Bhullar P, Ghaffari E, Liu M, Symonds AL and Wang P: The transcription factors Egr2 and Egr3 are essential for the control of inflammation and antigen-induced proliferation of B and T cells. Immunity 37: 685-696, 2012.

44. Liu D, Evans I, Britton G and Zachary I: The zinc-finger transcription factor, early growth response 3 , mediates VEGF-induced angiogenesis. Oncogene 27: 2989-2998, 2008.

45. Cheng H, Hao S, Liu Y, Pang Y, Ma S, Dong F, Xu J, Zheng G, Li S, Yuan W, et al: Leukemic marrow infiltration reveals a novel role for Egr3 as a potent inhibitor of normal hematopoietic stem cell proliferation. Blood 126: 1302-1313, 2015

46. Marcucci G, Maharry K, Radmacher MD, Mrózek K, Vukosavljevic T, Paschka P, Whitman SP, Langer C, Baldus CD, Liu CG, et al: Prognostic significance of, and gene and microRNA expression signatures associated with, CEBPA mutations in cytogenetically normal acute myeloid leukemia with high-risk molecular features: A Cancer and Leukemia Group B Study. J Clin Oncol 26: 5078-5087, 2008

47. Soon PS, Tacon LJ, Gill AJ, Bambach CP, Sywak MS, Campbell PR, Yeh MW, Wong SG, Clifton-Bligh RJ, Robinson BG, et al: miR-195 and miR-483-5p identified as predictors of poor prognosis in adrenocortical cancer. Clin Cancer Res 15: 7684-7692, 2009.
48. Xu Y, Zhao F, Wang Z, Song Y, Luo Y, Zhang X, Jiang L, Sun Z, Miao Z and Xu H: MicroRNA-335 acts as a metastasis suppressor in gastric cancer by targeting Bcl-w and specificity protein 1. Oncogene 31: 1398-1407, 2012.

49. Vickers MM, Bar J, Gorn-Hondermann I, Yarom N, Daneshmand M, Hanson JE, Addison CL, Asmis TR, Jonker DJ, Maroun J, et al: Stage-dependent differential expression of microRNAs in colorectal cancer: Potential role as markers of metastatic disease. Clin Exp Metastasis 29: 123-132, 2012.

50. Olson P, Lu J, Zhang H, Shai A, Chun MG, Wang Y, Libutti SK, Nakakura EK, Golub TR and Hanahan D: MicroRNA dynamics in the stages of tumorigenesis correlate with hallmark capabilities of cancer. Genes Dev 23: 2152-2165, 2009.

51. Yang W, Lee DY and Ben-David Y: The roles of microRNAs in tumorigenesis and angiogenesis. Int J Physiol Pathophysiol Pharmacol 3: 140-155, 2011.

52. Polytarchou C, Iliopoulos D and Struhl K: An integrated transcriptional regulatory circuit that reinforces the breast cancer stem cell state. Proc Natl Acad Sci USA 109: 14470-14475, 2012.

53. Liu H, Li W, Chen $\mathrm{C}$, Pei Y and Long X: miR-335 acts as a potential tumor suppressor miRNA via downregulating ROCK1 expression in hepatocellular carcinoma. Tumour Biol 36: 6313-6319, 2015.

54. Wang H, Li M,Zhang R, Wang Y,Zang W, Ma Y,Zhao G and Zhang G: Effect of miR-335 upregulation on the apoptosis and invasion of lung cancer cell A549 and H1299. Tumour Biol 34: 3101-3109, 2013.

55. Yang B, Huang J, Liu H, Guo W and Li G: miR-335 directly, while miR-34a indirectly modulate survivin expression and regulate growth, apoptosis, and invasion of gastric cancer cells. Tumour Biol 37: 1771-1779, 2016.

56. Scarola M, Schoeftner S, Schneider C and Benetti R: miR-335 directly targets $\mathrm{Rb} 1$ (pRb/p105) in a proximal connection to p53-dependent stress response. Cancer Res 70: 6925-6933, 2010.

57. Qiao J, Lee S, Paul P, Theiss L, Tiao J, Qiao L, Kong A and Chung DH: miR-335 and miR-363 regulation of neuroblastoma tumorigenesis and metastasis. Surgery 154: 226-233, 2013.

58. Tomé M, López-Romero P, Albo C, Sepúlveda JC, Fernández-Gutiérrez B, Dopazo A, Bernad A and González MA: miR-335 orchestrates cell proliferation, migration and differentiation in human mesenchymal stem cells. Cell Death Differ 18: 985-995, 2011

59. Grivennikov SI, Greten FR and Karin M: Immunity, inflammation, and cancer. Cell 140: 883-899, 2010.

60. Balkwill FR and Mantovani A: Cancer-related inflammation: Common themes and therapeutic opportunities. Semin Cancer Biol 22: 33-40, 2012.

61. Shu M, Zhou Y, Zhu W, Zhang H, Wu S, Chen J and Yan G: MicroRNA 335 is required for differentiation of malignant glioma cells induced by activation of cAMP/protein kinase A pathway. Mol Pharmacol 81: 292-298, 2012.

62. Xiong SW, Lin TX, Xu KW, Dong W, Ling XH, Jiang FN, Chen G, Zhong WD and Huang J: MicroRNA-335 acts as a candidate tumor suppressor in prostate cancer. Pathol Oncol Res 19: 529-537, 2013.

63. Suzuki T, Inoue A, Miki Y, Moriya T, Akahira J, Ishida T, Hirakawa H, Yamaguchi Y, Hayashi S and Sasano H: Early growth responsive gene 3 in human breast carcinoma: A regulator of estrogen-meditated invasion and a potent prognostic factor. Endocr Relat Cancer 14: 279-292, 2007.

64. Fang F, Shangguan AJ, Kelly K, Wei J, Gruner K, Ye B, Wang W, Bhattacharyya S, Hinchcliff ME, Tourtellotte WG, et al: Early growth response 3 (Egr-3) is induced by transforming growth factor- $\beta$ and regulates fibrogenic responses. Am J Pathol 183: 1197-1208, 2013

65. Gómez-Martín D, Díaz-Zamudio M, Galindo-Campos M and Alcocer-Varela J: Early growth response transcription factors and the modulation of immune response: Implications towards autoimmunity. Autoimmun Rev 9: 454-458, 2010.

66. Rojas A, Liu G, Coleman I, Nelson PS, Zhang M, Dash R, Fisher PB, Plymate SR and Wu JD: IL-6 promotes prostate tumorigenesis and progression through autocrine cross-activation of IGF-IR. Oncogene 30: 2345-2355, 2011.

67. Singh RK and Lokeshwar BL: Depletion of intrinsic expression of Interleukin-8 in prostate cancer cells causes cell cycle arrest, spontaneous apoptosis and increases the efficacy of chemotherapeutic drugs. Mol Cancer 8: 57, 2009.

This work is licensed under a Creative Commons Attribution-NonCommercial-NoDerivatives 4.0 International (CC BY-NC-ND 4.0) License. 